\title{
Experimental Heat Transfer Study on Green Roofs in a Semiarid Climate during Summer
}

\author{
Roy J. Issa, ${ }^{1}$ Kenneth Leitch, ${ }^{1}$ and Byungik Chang ${ }^{2}$ \\ ${ }^{1}$ West Texas A\&M University, Canyon, TX 79016, USA \\ ${ }^{2}$ University of New Haven, West Haven, CT 06516, USA \\ Correspondence should be addressed to Roy J. Issa; rissa@wtamu.edu
}

Received 3 September 2014; Revised 22 December 2014; Accepted 26 December 2014

Academic Editor: Mohsen Issa

Copyright (c) 2015 Roy J. Issa et al. This is an open access article distributed under the Creative Commons Attribution License, which permits unrestricted use, distribution, and reproduction in any medium, provided the original work is properly cited.

\begin{abstract}
An experimental study was conducted on green roofs under the semiarid summer climatic conditions of West Texas to investigate the effect of soil type, moisture content, and the presence of a top soil grass layer on the conductive heat transfer through the roof. Two soil types were investigated: uniform sand and local silt clay. Tests were also conducted on a control roof. A dual-needle heatpulse sensor was used to conduct thermal property tests on the soils. The tests reveal that unlike sand, the thermal conductivity of silt clay did not increase continuously with soil moisture. Better heat transfer conditions were achieved when the sand and silt clay roofs were watered to a water depth of $10 \mathrm{~mm}$ per day rather than double the amount of $20 \mathrm{~mm}$ per day. The roof with silt clay soil had the lowest fluctuation in inner temperature between daytime and nighttime. Green roofs with silt clay soil required more than twice the amount of soil moisture than green roofs with sand to achieve similar roof heat transfer rates. The best net heat flux gains for vegetated green roofs were $4.7 \mathrm{~W} / \mathrm{m}^{2}$ for the sand roof and $7.8 \mathrm{~W} / \mathrm{m}^{2}$ for the silt clay roof.
\end{abstract}

\section{Introduction}

During the last few years, several cities in North America have seen a surge in interest in installing green roofs (referred to as ecoroofs) in both retrofit and new construction buildings. A green roof is a roof that can be partially or completely covered with vegetation. Besides making the building attractive from aerial view, there are many benefits associated with green roofs in comparison to conventional roofs. A green roof improves storm water management. Plants and soil can retain storm water and, therefore, significantly mitigate storm water runoff generation. Water volume retention capability can range from $40 \%$ to $80 \%$ of the total rainfall volume depending on the structure of the green roof, climate conditions, and precipitation amount [1]. Another benefit of a green roof is that it extends the life of the roof by protecting it from the weather elements and thus reduces the maintenance costs on the roof. Green roofs have only been used extensively in the United States within the last twenty years. Studies conducted on green roofs in Europe [2] have shown their life span have exceeded twice the life span of conventional roofs. Green roofs can help lessen air pollution and carbon dioxide emissions. Studies have shown that a green roof with a surface area of $218 \mathrm{~m}^{2}$ planted with Ixora chinensis can lower the carbon dioxide concentration in the nearby region by as much as 2\% [3]. Yang et al. [4] quantified the impact of green roofs on air pollution in Chicago. Their results showed that pollutants such as ozone, $\mathrm{NO}_{2}, \mathrm{SO}_{2}$, and $\mathrm{PM}_{10}$ were removed at a rate of $85 \mathrm{~kg} / \mathrm{ha} / \mathrm{yr}$. Green roofs are also shown to reduce road traffic noise. van Renterghem et al. [5] have identified favorable combinations of roof shapes and green roofs that led to noise reductions of up to $7.5 \mathrm{dBA}$ in innercity buildings.

Green roofs improve building energy efficiency by lowering the cooling demand of the building during summer and the heating demand during winter due to the extra roof insulation they provide. A numerical simulation study conducted by Jaffal et al. [6] on a single-family house shows the annual energy demand to be reduced by $6 \%$. In summer time, the fluctuation amplitude of the roof is shown to be reduced by $30^{\circ} \mathrm{C}$ due to the green roof. Several other studies have also shown that green roofs improve building energy efficiency by enhancing the heat transfer through 


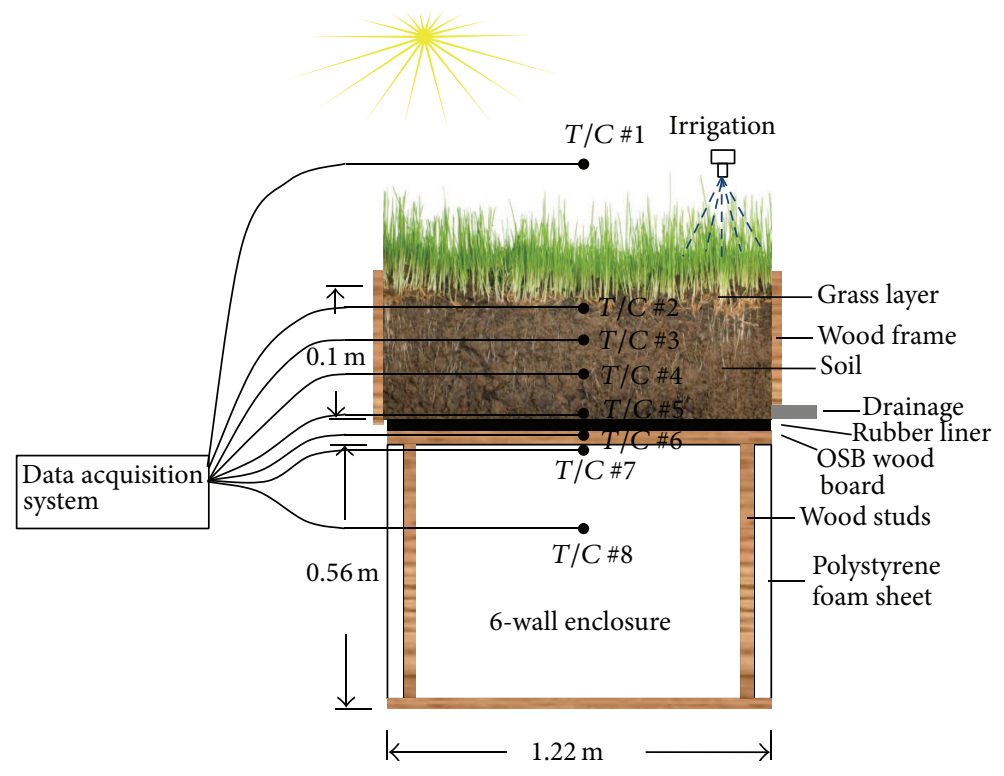

FIGURE 1: Green roof experimental setup diagram.

roofs [7-12]. The choice of a green roof depends on the climate of the region. For example, the substrates and plants used in constructing green roofs in Australia differ from those suitable for a European climate [13]. Studies were also conducted on the choice of suitable plant species to use for green roofs in certain climates such as Midwestern climates [14], humid subtropical climates [15], and dry climates [16]. However, from the review of open literature there is a lack in the research conducted on the use of green roofs in semiarid climates and on the use of silt clay soil in the construction of the green roof. The main objectives of this study are:

(i) to establish an understanding of the performance of a green roof in the rural dry and hot climate of West Texas using the local silt clay soil of the region;

(ii) to evaluate the thermal properties of the local silt clay soil used in the green roof construction through an experimental approach;

(iii) to determine the thermal benefit of the green roof by specifically determining the reduction in the conductive heat transfer through the roof.

\section{Experimental Setup}

A test model of a green roof was built at the Alternative Energy Institute on the West Texas A\&M University Campus as shown in Figure 1. The system consisted of a six-wall enclosure having a base of dimensions $1.22 \mathrm{~m} \times 1.22 \mathrm{~m}$. The top and bottom surfaces of the enclosure were constructed of $0.019 \mathrm{~m}$ thick OSB (Oriented Strand Board) wood panels, while the sides were constructed of $0.05 \mathrm{~m}$ thick polystyrene foam panels. Extra support for the roof was provided by twelve, $5 \mathrm{~cm}$ by $5 \mathrm{~cm}$ vertical supports. Wheels were added to the bottom to aid positioning the boxes. Spray foam was injected into the polystyrene panel seams to prevent air flow.
To prevent water from leaking onto or into the box, the top was lined with a rubberized pond liner. Soil was poured over the liner to a height of $10 \mathrm{~cm}$. In some tests sand was used, while in others native silt clay from Canyon, Texas, was used. Also, in some tests a layer of grass (sod), $5 \mathrm{~cm}$ thick, was added to the top soil surface. A water drainage hose was affixed to one corner of the roof to prevent excess irrigation water from accumulating on the roof. As shown in Figure 1, thermocouples were installed at various locations to monitor the temperature: in the air $(T / C \# 1)$, in the soil at $1 \mathrm{~cm}(T / C$ $\# 2), 4 \mathrm{~cm}(T / C \# 3)$, and $7 \mathrm{~cm}(T / C \# 4)$ from the soil top surface, at the interface between the rubberized liner and soil bottom surface $(T / C \# 5)$, on the roof's outer $(T / C \# 6)$ and inner $(T / C \# 7)$ plywood surfaces, and in the center of the sixwall enclosure $(T / C \# 8)$. The air temperature was measured at about 5 feet above the soil surface. The thermocouple $(T / C$ \#1) was shielded to prevent radiation error. Soil moisture content was estimated by taking a soil sample at a depth of around 2 to $3 \mathrm{~cm}$ from the soil surface twice a day and measuring its mass before and after holding it to dry for 24 hours in an oven. Wind speed and relative humidity data were provided by the Alternative Energy Institute weather station at WTAMU. All thermocouples were connected to a data acquisition device (OMEGA Engineering Inc., OM-SQ20402F16) that recorded the data at a sampling rate of one data point every two minutes. For all tests, temperature data were recorded for recurring periods consisting of three days. Data was pulled every third day and then data logger was reset to continue data collection.

Several tests were conducted between July and August. Tests were conducted on a single green roof and a single control roof. The green roof tests investigated the effect of two soil types (sand and silt clay soil), moisture content in the soil, and the presence of a top soil grass layer (sod) on the heat transfer through a green roof. The control roof tests 
TABLE 1: Properties of soils used in the study.

\begin{tabular}{lcc}
\hline & Sand & Silt clay \\
\hline Gravel \% & 0.0 & 11.9 \\
Sand \% & 99.9 & 78.1 \\
Fines (silt and clay) \% & 0.1 & 10.0 \\
Specific gravity of solids & 2.29 & 2.67 \\
Bulk density $\left(\mathrm{g} / \mathrm{cm}^{3}\right)$ & 1.64 & 1.12 \\
USCS soil type & SP & SW-SC \\
\hline
\end{tabular}

were conducted on a roof that had dimensions identical to that of the green roof shown in Figure 1. The roof consisted only of plywood without vegetation, soil, or roof rubber liner. The thermocouples that are used to measure the temperature in the control roof are as follows: $T / C \# 6, \# 7$, and \#8. In the case of the green roof tests, the silt clay tests started after the sand tests were concluded.

\section{Characterization of Soil Materials}

Two types of soil materials were used in the present study. One soil type was washed play sand produced by the Quikrete Company for use with sandboxes and playground equipment. The other soil type was a native soil obtained from a vacant lot located on the Campus of West Texas A\&M University in Canyon, Texas. These soil materials were evaluated for their soil characteristics using basic principles in geotechnical engineering as well as for their thermal properties as described in Section 4. The sand represents a typical noncohesive soil while the native soil with clay content represents a typical cohesive soil that could be encountered when constructing a green roof.

A mechanical sieve analysis using standard $20 \mathrm{~cm}$ (8 in) brass sieves of sizes from $4.75 \mathrm{~mm}$ (number 4 ) down to $0.075 \mathrm{~mm}$ (number 200) was performed for each soil type, the play sand (i.e., sand), and the native soil (i.e., silt clay). Tests to determine the specific gravity and noncompacted bulk density of the soils were also performed. A brief synopsis of the tests and resultant Unified Soil Classification System (USCS) [17] soil types are given in Table 1.

\section{Measurement of Thermal Properties}

Test samples of two soil types (sand and silt clay) were tested in a laboratory experimental setup for the determination of thermal properties: thermal conductivity, thermal diffusivity, and specific heat. A dual-needle heat-pulse sensor, KD2 Pro, by Decagon Devices (Figure 2) was used to conduct thermal property tests. The system consists of two parallel needles made of 304 stainless steel material and spaced $6 \mathrm{~mm}$ apart. One needle is used as a heating element subjected to a short duration heating pulse, while the other needle is used for monitoring the temperature. The thermocouple's temperature response to the heat pulse is used to simultaneously determine the thermal conductivity and diffusivity. The volumetric specific heat is then determined from these parameters. The dual-needle algorithm was presented by

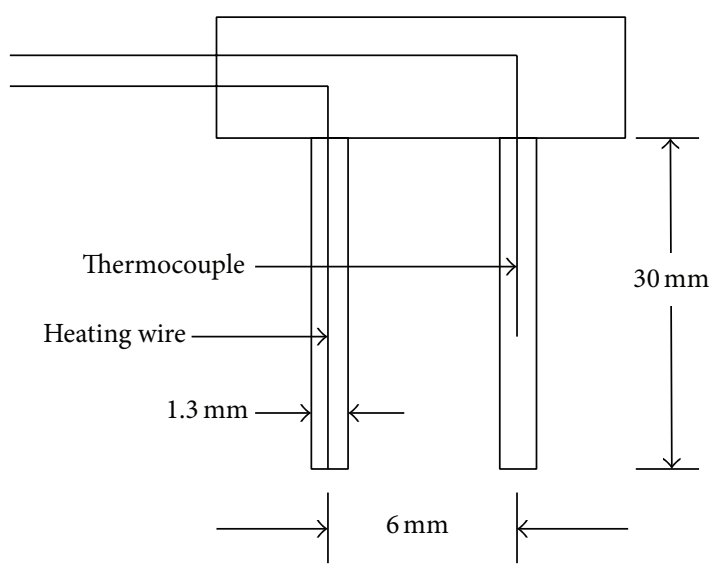

Figure 2: Dual needle heat pulse sensor.

Kluitenberg et al. [18], and details about the design and working of the KD2-Pro device can be found in the operator's manual [19]. The uncertainty in the measurement of thermal conductivity and thermal diffusivity was calculated from repeated tests to be $\pm 10 \%$, and the uncertainty in the calculation of the specific heat was $\pm 14 \%$.

Equation (1) is used in curve fitting the temperature time history when the heater is turned on for duration of $t_{h}(0<$ $\left.t<t_{h}\right)$ :

$$
T(t)=T_{i}+\frac{q b_{o}}{4 \pi} t+\frac{q b_{1}}{4 \pi} \operatorname{Ei}\left(\frac{b_{2}}{t}\right)
$$

and (2) is used when the heater is turned off $\left(t>t_{h}\right)$ :

$$
T(t)=T_{i}+\frac{q b_{o}}{4 \pi} t+\frac{q b_{1}}{4 \pi}\left[\operatorname{Ei}\left(\frac{b_{2}}{t}\right)-\operatorname{Ei}\left(\frac{b_{2}}{t-t_{h}}\right)\right],
$$

where Ei is an exponential integral evaluated using the following infinite series:

$$
\operatorname{Ei}(\zeta)=\gamma+\ln (\zeta)+\sum_{n=1}^{\infty} \frac{\zeta^{n}}{n n !}
$$

where $\gamma$ is Euler-Mascheroni constant and $\zeta$ is an arbitrary variable. Constants $b_{o}, b_{1}$, and $b_{2}$ are calculated using least square procedure. The thermal conductivity and diffusivity are then obtained as follows:

$$
\begin{gathered}
k=\frac{1}{b_{1}}, \\
\alpha=\frac{\Delta^{2}}{4 b_{2}} .
\end{gathered}
$$

Figures 3 and 4 show the average thermal properties of repeated measurements on sand and silt clay soil samples, respectively, at various soil moisture levels using the dual needle heat pulse sensor. Compared to a dry soil, moist soil is more conductive. This is because water helps to bridge the gaps between the soil particles and increase the contact surface area. Figure 3 shows the thermal conductivity of sand 
Journal of Construction Engineering

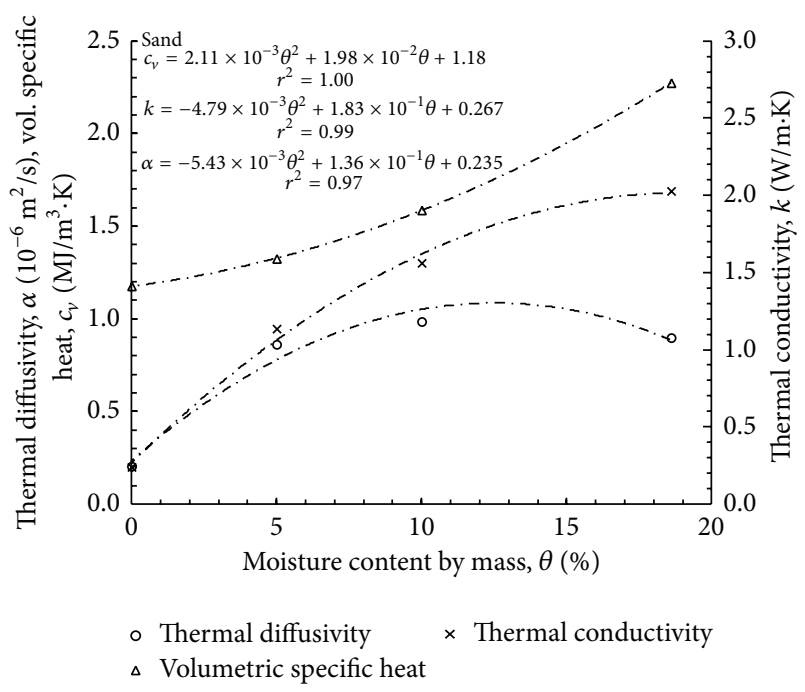

FIgURE 3: Thermal properties of sand at different moisture levels.

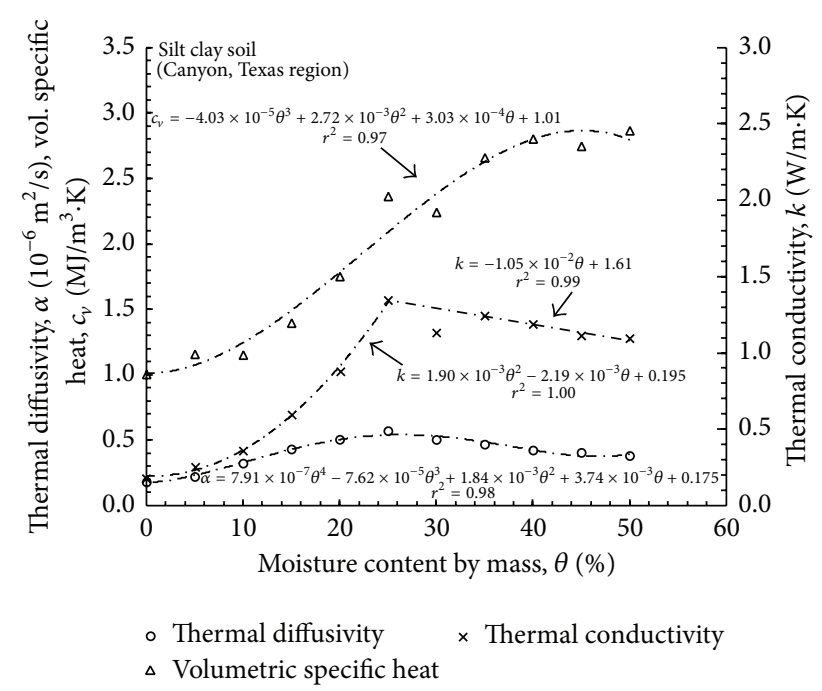

FIgURE 4: Thermal properties of silt clay soil at different moisture levels.

keeps on increasing until saturation conditions are reached around a moisture content (by mass) of 19\%. However, for the silt clay soil (Figure 4), the thermal conductivity reaches a peak at a moisture content of $25 \%$ but decreases with the addition of more water. Unlike sand, clay bonds tightly to the water and does not let it drain easily. As a result, surface flooding occurs and the thermal conductivity of the soil/water mixture decreases as it approaches that of liquid water. A similar effect of moisture on clay soil behavior has been reported by Abu-Hamdeh [20] and Ekwue et al. [21].

Thermal conductivity and diffusivity of sand and clay soils at different moisture levels were reported in the open literature. Haynes et al. [22], Abu-Hamdeh et al. [23], and Bristow et al. [24] conducted studies on sand thermal conductivity. Bristow [25] and Bristow et al. [24] conducted studies on sand thermal diffusivity. The thermal conductivity and diffusivity results of these tests along with the results
TABLE 2: Thermal properties of green roof construction material.

\begin{tabular}{lccc}
\hline Property & OSB wood & Rubber liner & $\begin{array}{c}\text { Polystyrene } \\
\text { foam }\end{array}$ \\
\hline$k(\mathrm{~W} / \mathrm{mK})$ & 0.128 & 0.176 & 0.036 \\
$c_{v}\left(\mathrm{MJ} / \mathrm{m}^{3} \mathrm{~K}\right)$ & 0.703 & 0.952 & 0.164 \\
$\alpha\left(10^{-6} \mathrm{~m}^{2} / \mathrm{s}\right)$ & 0.182 & 0.185 & 0.219 \\
\hline
\end{tabular}

TABLE 3: Uncertainty in experimental data.

\begin{tabular}{lc}
\hline Variable & Uncertainty \\
\hline Temperatures (K-type thermocouples) & $\pm 1.1^{\circ} \mathrm{C}$ \\
Dimensions & $\pm 0.03 \mathrm{~mm}$ \\
Thermal conductivity and diffusivity & $\pm 10 \%$ \\
Specific heat & $\pm 14 \%$ \\
\hline
\end{tabular}

of the current study are shown in Figures 5(a) and 5(b), respectively. Overall, the thermal property measurements of the current study on sand compared well with the published data. Nikiforova et al. [26] studied the thermal conductivity of loam soil in Pridneprovsk, Ukraine. Abu-Hamdeh [27] and Abu-Hamdeh et al. [23] measured the thermal conductivity of clay loam soil in Irbid, Jordan, while Ekwue et al. [28] measured clay loam thermal conductivity in Maracas, Trinidad, and Al Nakshabandi and Kohnke [29] measured the thermal conductivity and diffusivity of clay and silt loam in Lafayette, Indiana. Oladunjoye and Sanuade [30] conducted thermal diffusivity tests on clay loam soil in Ogun, Nigeria. Tikhonravova [31] tested the thermal diffusivity of clay loam soil in the Transvolga region in Russia. The results of these studies together with the current study are shown in Figures 5(c) and 5(d), respectively. The results show the thermal conductivity and diffusivity of silt loam to be the highest and clay to be the lowest. The thermal conductivity and diffusivity of silt clay were between those values. Table 2 shows the average thermal properties of repeated measurements using the dual needle heat pulse sensor on test specimens of other material (OSB wood, rubber liner, and polystyrene foam) used in the construction of the green roof system. Table 3 shows the uncertainties in all the experimental data.

\section{Energy Balance}

Temperature measurements were taken at various depth locations in the soil and on both surfaces of the green roof's OSB wood panel. The geometry of the constructed green roof (Figure 1) is such that the thickness dimension ( $x$ axis) is much smaller than the other two dimensions in the lateral directions ( $y$-and $z$-axis). The composite roof thickness ranged from 11.9 (without grass layer) to $14.4 \mathrm{~cm}$ (with grass layer), while the width and the depth of the roof were $121.9 \mathrm{~cm}$ each (a factor of 8.5 to 10.2 larger than the thickness). Temperature data collected at different locations in the soil also showed the temperature gradient in $x$ direction to be much larger than that in the lateral directions. As a result, only the heat transfer in the thickness direction was considered in the energy balance and that in the lateral 


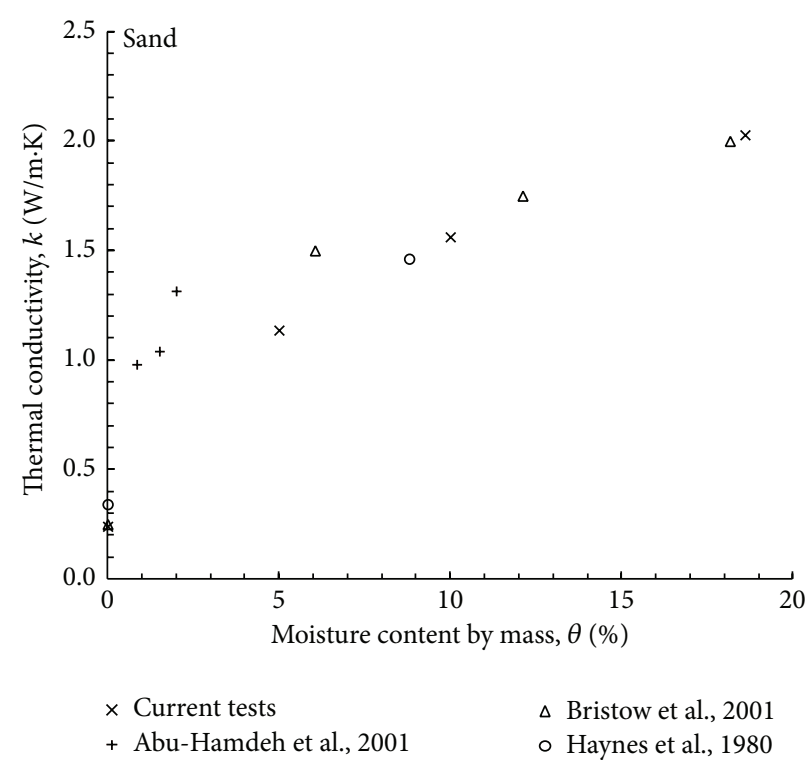

(a) Thermal conductivity of sand

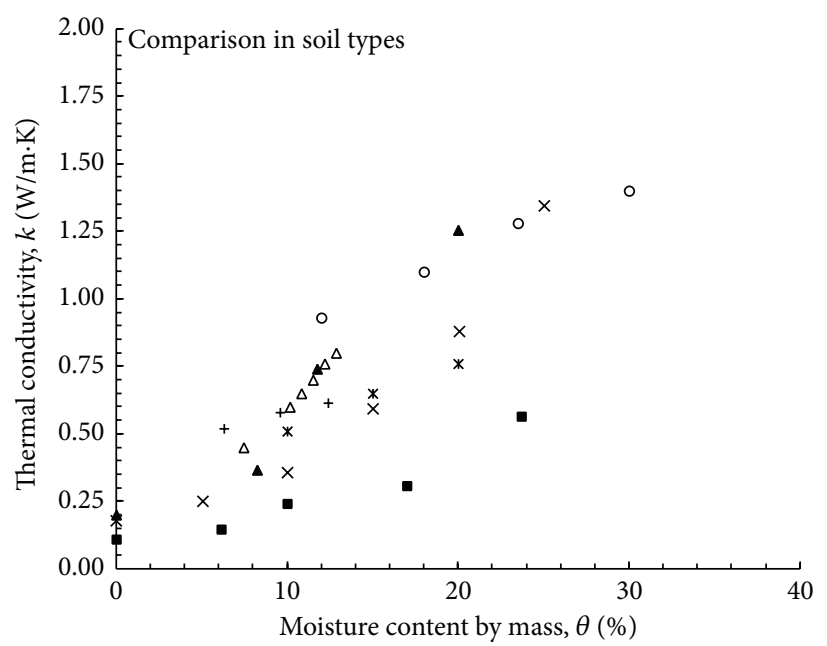

$\times$ Current tests (Canyon, Texas-silt clay)

+ Abu-Hamdeh et al., 2001 (Irbid, Jordan-clay loam)

$\triangle$ Abu-Hamdeh, 2000 (Irbid, Jordan-clay loam)

- Ekwue et al., 2011 (Maracas, Trinidad-clay loam)

* Nikiforova et al., 2013 (Pridneprovsk region, Ukraine-loam)

- Al Nakshabandi and Kohnke, 1965 (Lafayette, Indiana-clay)

- Al Nakshabandi and Kohnke, 1965

(Lafayette, Indiana-silt loam)

(c) Thermal conductivity of various soil types

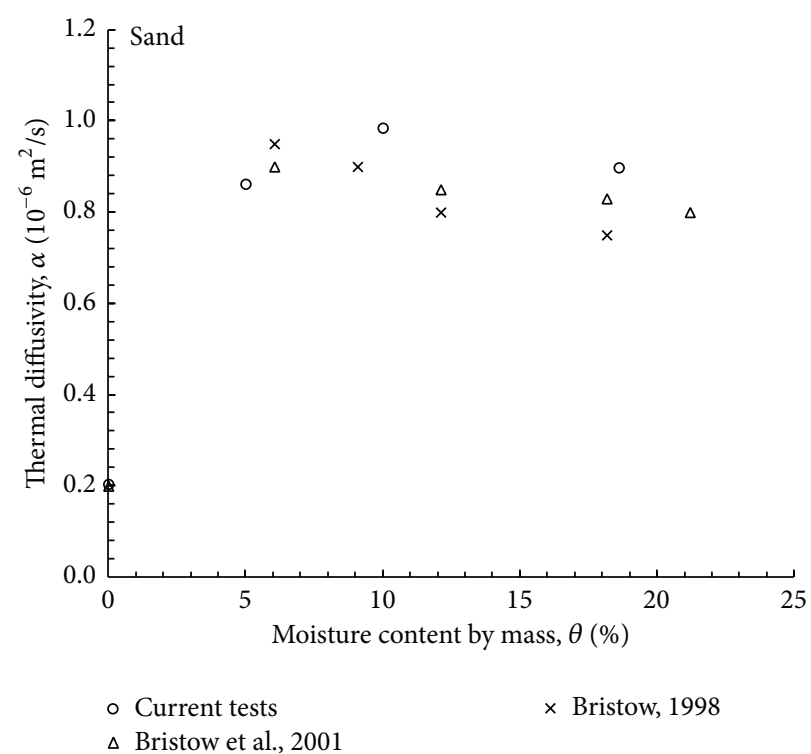

(b) Thermal diffusivity of sand

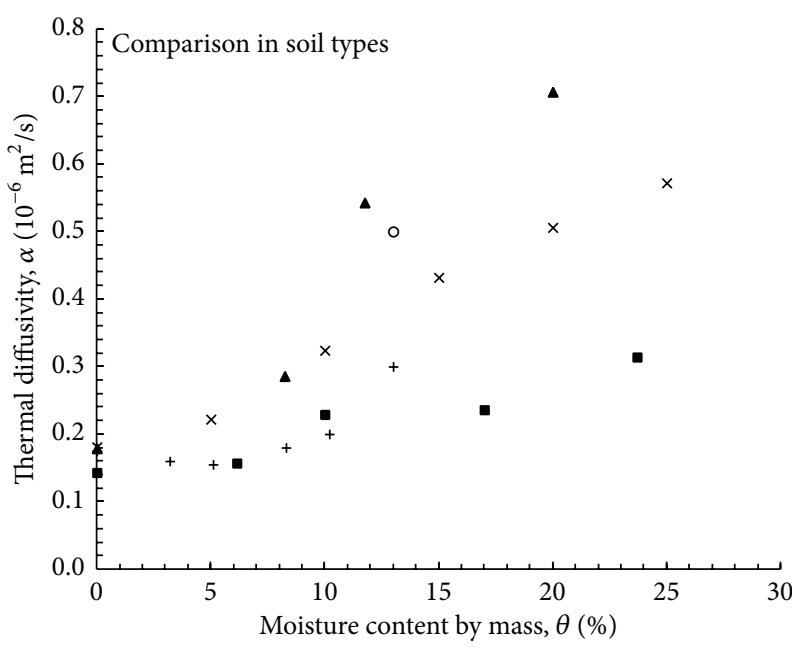

$\times$ Current study (Canyon, Texas-silt clay)

- Oladunjoye and Sanuade, 2012 (Ogun, Nigeria-clay loam)

+ Tikhonravova, 2007 (Transvolga region, Russia-clay loam)

- Al Nakshabandi and Kohnke, 1965 (Lafayette, Indiana-clay)

- Al Nakshabandi and Kohnke, 1965

(Lafayette, Indiana-silt loam)

(d) Thermal diffusivity of various soil types

FIGURE 5: Comparison of current study soil thermal properties with other studies.

directions was neglected. Also, because of the heavy weight exerted by the soil on the roof, it is assumed that there is perfect contact at the interface between the soil/rubber liner and rubber liner/OSB wood panel.

Energy balance (on a time rate basis) applied on a thin boundary layer at the vegetated roof top is written as

$$
\dot{E}_{\text {in }}=\dot{E}_{\text {out }} \text {. }
$$

Substituting for the different forms of input and output energies, (5) can be expressed as

$$
\left(q_{\mathrm{sr}}+q_{\mathrm{lr}}\right)_{\mathrm{in}}=\left(q_{\mathrm{cv}}+q_{\mathrm{er}}+q_{\mathrm{tp}}+q_{\mathrm{ep}}+q_{\mathrm{cd}, x=0}\right)_{\mathrm{out}} .
$$

Energy entering the soil and vegetation layer from the upper surface consist of absorbed solar radiation, $q_{\mathrm{sr}}$, and long-wave radiation, $q_{\mathrm{lr}}$. Energy leaving the upper surface consists of heat loss by convection, $q_{\mathrm{cv}}$, heat loss by emitted radiation, 


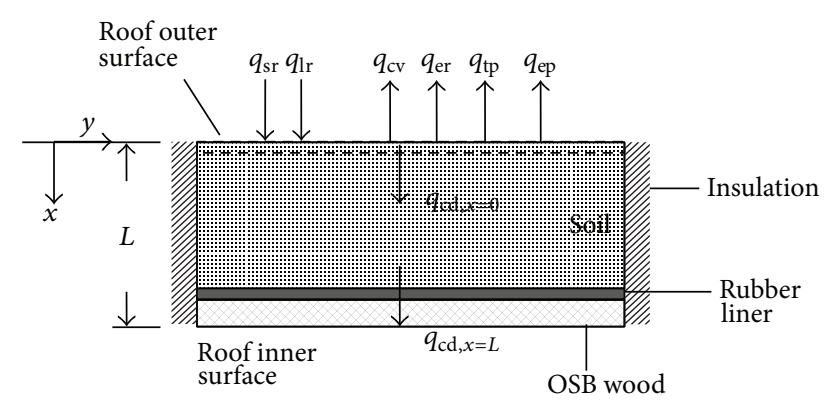

FIGURE 6: Sketch of energy balance on a green roof.

$q_{\mathrm{er}}$, heat loss by transpiration, $q_{\mathrm{tp}}$, and heat loss by water evaporation from the soil, $q_{\mathrm{ep}}$. Energy leaving from the lower surface of the thin boundary layer consists of heat transfer by conduction at $x=0, q_{\mathrm{cd}, x=0}$. Figure 6 shows the energy balance.

Heat transfer through the green roof is an unsteady state process due to the continuous variation in the surrounding boundary conditions (such as ambient temperature, wind speed, precipitation, and humidity). As a result, conduction heat transfer through the top layer of the soil will differ from that through the bottom layer because of the thermal energy that is stored in the soil. Since steady state conditions cannot be achieved, the thermal resistors method will not be a valid one to use in predicting the heat transfer through the roof.

Heat transfer test measurements were performed at a location in the center of the roofs as shown in Figure 1. The geometry of the roof was approximated by that a slab. For all green roof tests (vegetated or nonvegetated), the thickness dimension ( $x$-axis) was much smaller than the other two dimensions $(1.22 \mathrm{~m})$ in the lateral directions ( $y$ - and $z$-axis). In addition, the edges in the lateral directions were insulated. The overall green roof thickness ranged from 11.9 for a nonvegetated roof to $17 \mathrm{~cm}$ for a vegetated one. Temperature data collected at different locations in the roof showed the temperature gradient in $x$ direction to be much larger than that in the lateral directions. For example, after several hours of being exposed to incoming solar radiation, temperature recordings at 2:40 pm on July 23, 2013 (part of test number 1 ) showed the temperature gradient in the thickness direction ( $x$-axis) close to the soil surface to be about $93^{\circ} \mathrm{C} / \mathrm{m}$ and that in the lateral directions to be $3^{\circ} \mathrm{C} / \mathrm{m}$. As a result, transient conduction heat transfer inside the composite roof material can be simplified to a one-dimensional problem (Figure 6):

$$
\rho c_{p} \frac{\partial T}{\partial t}=\frac{\partial}{\partial x}\left(k \frac{\partial T}{\partial x}\right),
$$

where $\rho$ and $c_{p}$ are the material average density and specific heat, respectively, of the composite roof material. The amount of energy conducted through the soil top layer, $q_{\mathrm{cd}, x=0}$, can be experimentally evaluated using Fourier's law for conduction (where the location $x=0$ denotes the roof top):

$$
q_{\mathrm{cd}, x=0}=-\left.k A \frac{d T}{d x}\right|_{x=0}=q_{\mathrm{net}}
$$

where $A$ is the roof surface area and $q_{\text {net }}=q_{\mathrm{sr}}+q_{\mathrm{lr}}-q_{\mathrm{cv}}-q_{\mathrm{er}}-$ $q_{\mathrm{tp}}-q_{\mathrm{ep}}$ is the net heat transfer at $x=0$ that is transmitted through the roof. The amount of energy conducted through the soil bottom layer, $q_{\mathrm{cd}, x=L}$, is

$$
q_{\mathrm{cd}, x=L}=-\left.k A \frac{d T}{d x}\right|_{x=L} .
$$

The net heat that is transmitted through the roof was predicted from temperature measurements inside the roof by means of inverse heat conduction. Equation (7) was discretized in space using finite difference method, with the explicit method used for time discretization. Fine grid size, $\Delta x$, was used to ensure numerical accuracy, and fine integration time step, $\Delta t$, based on the following stability criterion was implemented to ensure numerical stability. For the roof surface node (node $m=1$ ) it can be shown that

$$
T_{1}^{p+1}=(1-2 \mathrm{Fo}) T_{1}^{p}+2 \mathrm{Fo}_{2}^{p}+2 \frac{q_{\mathrm{net}} \Delta x}{k A} \mathrm{Fo}
$$

and for the roof interior nodes $(1<m<M)$

$$
T_{m}^{p+1}=(1-2 \mathrm{Fo}) T_{m}^{p}+\mathrm{Fo} T_{m-1}^{p}+\mathrm{Fo} T_{m+1}^{p},
$$

where $M$ is the total number of nodes (25). Surface temperature boundary condition based on test data is imposed at the roof interior surface. Fourier number, Fo, is defined as

$$
\text { Fo }=\frac{\alpha \Delta t}{(\Delta x)^{2}}
$$

For any given value of $q_{\text {net }},(10)$ and (11) were solved numerically, and the temperature inside the roof was calculated. The error, $\omega$, between the calculated temperature, $T_{\text {cal }}$, and the experimental temperature, $T_{\text {exp }}$, at different nodes was then evaluated using the following equation:

$$
\omega=\sqrt{\frac{\sum_{i=1}^{l}\left[T_{\text {exp }}(i)-T_{\text {cal }}(i)\right]^{2} \Delta t}{t_{\text {total }}}},
$$

where $t_{\text {total }}$ is the total time of each test and $l$ is the total number of time steps. By changing the value of $q_{\text {net }}$, $\omega$ was calculated for that particular value of $q_{\text {net }}$. The predicted value of $q_{\text {net }}$ was the one that corresponded to the smallest error. The heat flux at the top and bottom soil layers was then calculated from (8) and (9) by dividing the transferred heat by the roof surface area, $A$.

\section{Results and Discussions}

Several tests were conducted to evaluate the effectiveness of a green roof under the climatic conditions of West Texas (Table 4). Two types of soils were tested: sand and a silt clay soil from canyon. Roofs with and without vegetation were tested. The tests were conducted between July 21 and August 22 , 2013, with the exception of few days when data was not collected. The first group of tests (July 21-August 4) used barren sand and barren silt clay soil. The second group of tests (August 5-August 16) used sand and silt clay soil with 
TABle 4: Average climatic conditions for the conducted tests.

\begin{tabular}{lccccccc}
\hline Test number & Dates (2013) & Description & $\begin{array}{c}\text { Watering/day } \\
(\mathrm{mm})\end{array}$ & $\begin{array}{c}\text { Wind speed } \\
(\mathrm{m} / \mathrm{s})\end{array}$ & $\begin{array}{c}\text { Average air } \\
\text { temperature } \\
\left({ }^{\circ} \mathrm{C}\right)\end{array}$ & $\begin{array}{c}\text { Precipitation } \\
\left(\mathrm{mm} \text { of } \mathrm{H}_{2} \mathrm{O}\right)\end{array}$ & $\begin{array}{c}\text { Relative } \\
\text { humidity }(\%)\end{array}$ \\
\hline 1 & $7 / 21-8 / 4$ & $\begin{array}{c}\text { Barren roofs with } \\
\text { sand or silt clay } \\
\text { Roofs with } \\
\text { vegetation }\end{array}$ & 0 & 5.1 & 26.0 & 20.3 & 61.6 \\
3 & $8 / 5-8 / 16$ & 4.1 & 24.1 & 109.5 & 66.1 \\
3 & $8 / 17-8 / 22$ & $\begin{array}{c}\text { Roofs with } \\
\text { vegetation }\end{array}$ & 10 & 5.9 & 24.7 & 0 & 54.5 \\
\hline
\end{tabular}

a layer of grass (sod) on top. The grass was watered twice a day to a water depth of $10 \mathrm{~mm}$ during each watering. The third group of tests (August 17-August 22) also used sand and silt clay soil with a layer of grass (sod) on top. In this case, the grass was watered once a day to a uniform water depth of $10 \mathrm{~mm}$. Alongside these tests, tests were also performed on a control roof (roof without soil and vegetation) during the entire period. The following parameters were measured for each test:

(i) outdoor ambient temperature, wind speed and relative humidity;

(ii) soil temperature at depths of 1,4 , and $7 \mathrm{~cm}$ from the surface;

(iii) soil moisture content;

(iv) inner and outer temperature of the roof's wood structure.

Figures 7(a)-7(c) show the ambient conditions (air temperature, wind speed, relative humidity, and precipitation) for the time period of the study. Precipitation occurred on particular days during this period with the heaviest rainfall occurring on July 25 and August 15, followed by a trace of precipitation on August 8-10. Precipitation and relative humidity peaked during test $2(109.5 \mathrm{~mm}, 66.1 \%)$ and dipped during test 3 $(0 \mathrm{~mm}, 54.5 \%)$. The average wind speed was the highest during test $3(5.9 \mathrm{~m} / \mathrm{s})$ and the lowest during test $2(4.1 \mathrm{~m} / \mathrm{s})$. The average air temperature peaked at $26.0^{\circ} \mathrm{C}$ for test 1 and dipped to $24.1^{\circ} \mathrm{C}$ for test 2 .

Figures $8(\mathrm{a})-8(\mathrm{c})$ show the variation in the soil moisture contents for the three performed tests. In test 1 no auxiliary watering was implemented. However, the soil moisture peaked at certain dates due to the precipitation that fell. In test 2 , the grass was watered twice per day for a total of $20 \mathrm{~mm}$ of water, and heavy precipitation occurred during this test. The soils moisture peaked close to the soils saturation limit. In test 3 , the auxiliary grass watering was reduced to $10 \mathrm{~mm}$ of water per day, but no precipitation occurred during this test. As a result, the soils moisture content dropped.

Figures 9(a)-9(c) show the roof inner temperature $(T / C$ \#7 in Figure 1) for the time period starting from July 21 to August 22, 2013. Temperature results for three different roofs were compared: roof with silt clay soil, roof with sand, and a control roof with no soil. The roof with silt clay soil had the lowest fluctuation in temperature between daytime and nighttime and the lowest temperature during daytime.
The roof with sand had a slightly higher temperature during daytime, while the control roof had the highest temperature during daytime. The fact that temperature fluctuations for the silt clay material were smaller in amplitude than those for the sand is a direct consequence of the fact that the thermal diffusivity of the silt clay is substantially smaller than that of the sand. The largest temperature fluctuation between daytime and nighttime was seen in the control roof, which also had the lowest temperature during nighttime due to the lack of a thermal mass providing heat. Figures 9(a)-9(c) also show that the inner temperature of the vegetated roofs (with silt clay soil or sand) dropped considerably during daytime compared to nonvegetated soils. It is also shown that doubling the amount of auxiliary grass watering from $10 \mathrm{~mm}$ to $20 \mathrm{~mm}$ per day hardly made a noticeable difference on the inner roof temperature. This result is entirely consistent with the fact that, for both soil materials, there is essentially no change in thermal diffusivity over the range of water contents realized in the experiments with the grass roof. The reason why the control roof behaved differently from either the silt clay or the sand green roof is that the thick layer of silt clay or sand acted as a thermal mass that provided for storage of heat during the daylight hours which was subsequently released to the exterior ambient and the six-walled enclosure during the nighttime hours.

Figures 10(a)-10(c) show the roof outer temperature $(T / C$ \#6 in Figure 1) for the time period starting from July 21 to August 22, 2013. Since the thermocouple in this case was located in the soil, the thermocouple did not measure soil/air interface or wind-chill temperature but soil temperature instead. When the soil was watered, the roof with silt clay showed larger temperature fluctuations than the roof with sand at its top surface. This behavior is opposite to what was observed in Figures 9(a)-9(c) where the thermocouple was sensing temperature at the bottom of the roof. Since sand cannot hold water like silt clay, the top layer of the sand roof quickly dries out as it gets exposed to radiation from the sun. Dry sand has a much lower thermal conductivity and diffusivity than moist silt clay. As a result, the top layer of a silt clay roof is more conductive (and more thermally diffusive) than that of a sand roof and, therefore, sees more temperature fluctuations. In comparison, Figures 9(a)-9(c) show the silt clay roof to have less temperature fluctuations than a sand roof. In this case, the bottom layer of a sand roof has more water than the bottom layer of a clay roof since a sand roof cannot hold water at its surface. As a result, 


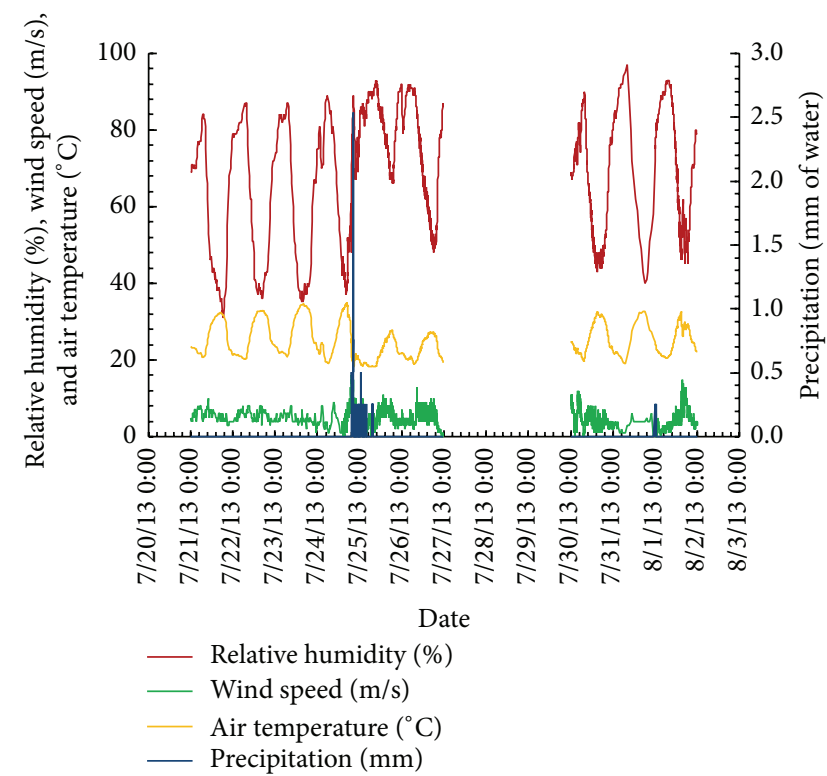

(a)

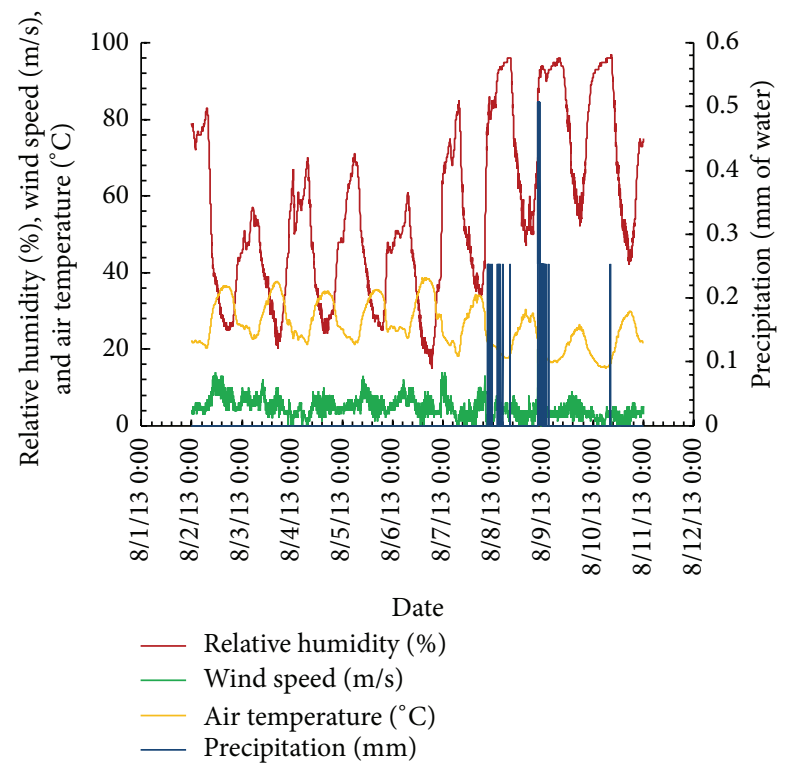

(b)

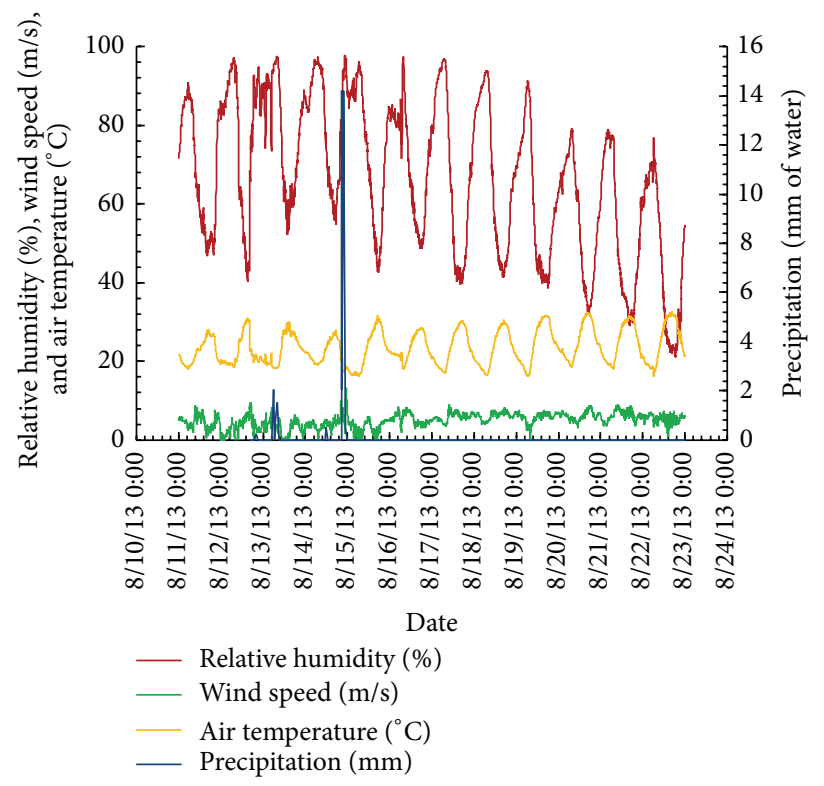

(c)

Figure 7: (a) Weather data (July 21-August 1, 2013). (b) Weather data (August 2-August 10, 2013). (c) Weather data (August 11-August 22, 2013).

the bottom layer of a sand roof is more conductive (and more thermally diffusive) than the bottom layer of a clay roof and, therefore, sees more temperature fluctuations.

Figures 11(a)-11(c) show the roof heat flux for the time period of the study. The control roof is shown to have the largest fluctuation in heat gain during daytime and heat loss during nighttime. A layer of soil on top of the roof substantially helps in reducing the heat entering the roof even if no vegetation layer is present. It is also shown that when a layer of vegetation (grass in this case) is added on top of the roof (either silt clay soil or sand) and the roof is watered, the amount of heat entering the roof reduces even further. However, it is shown that by doubling the amount of grass watering from $10 \mathrm{~mm} /$ day to $20 \mathrm{~mm}$ /day, no further benefit was achieved. In fact, the heat flux entering the roof slightly increased. The addition of water to a layer of soil and grass reduces the amount of heat transmitted through the roof during daytime hours because of the evaporation and transpiration that take place at the soil/vegetation surface. This amount of heat removal is due to the latent heat of vaporization. Adding extra water on the roof will not enhance soil evaporation. Instead, it will make the soil more conductive and, therefore, will cause larger fluctuations in temperature as the results in Figure 11(c) reveal. 


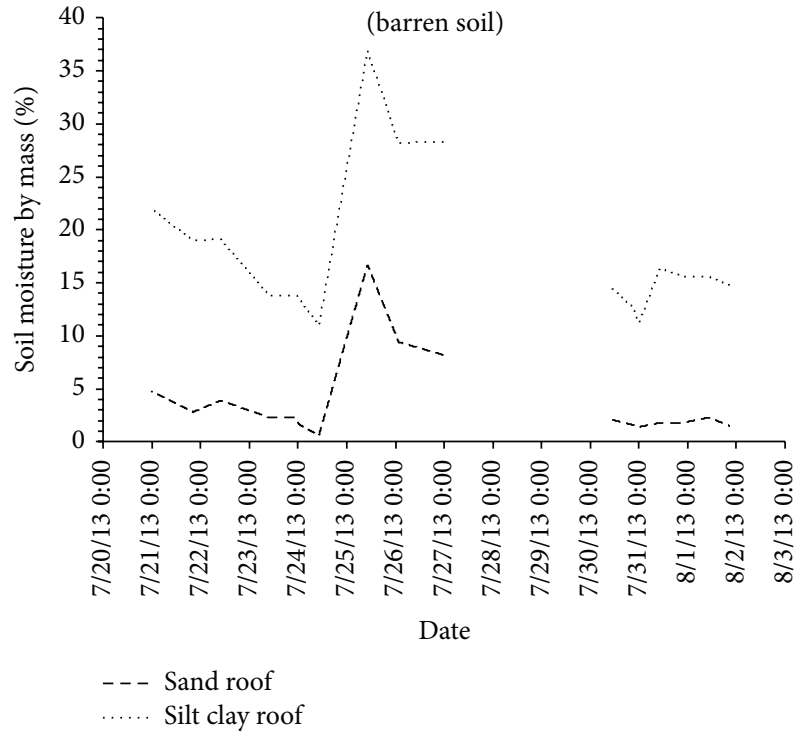

(a)

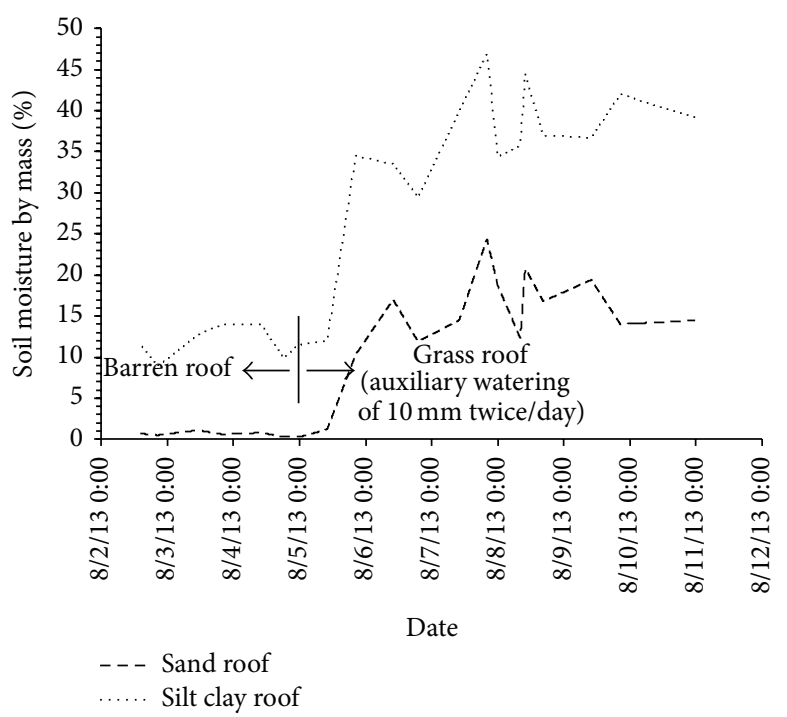

(b)

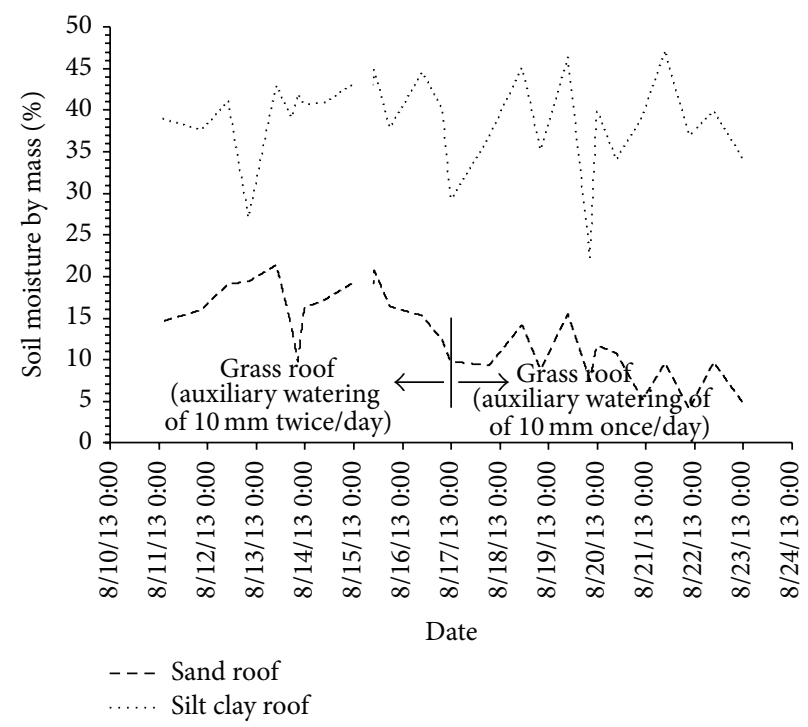

(c)

Figure 8: (a) Soil moisture (July 21-August 1, 2013). (b) Soil moisture (August 2-August 10, 2013). (c) Soil moisture (August 11-August 22, 2013).

The net heat flux gained by the roof for the duration of each test is calculated and plotted as function of the soil moisture content. The results are shown in Figure 12. The control roof shows a gain of $44 \mathrm{~W} / \mathrm{m}^{2}$. Compared to the control roof, barren roofs (without grass, test 1) using either sand or silt clay provide sufficient insulation to slow down conductive heat transfer process. The results show significant heat transfer improvement even without the grass layer and the auxiliary daily watering $\left(29.5 \mathrm{~W} / \mathrm{m}^{2}\right.$ for sand and $22.8 \mathrm{~W} / \mathrm{m}^{2}$ for silt clay). This accounts to about $33 \%$ reduction in heat gain for the barren sand roof and $48 \%$ reduction in heat gain for the barren silt clay roof. When a grass layer was placed on the sand and silt clay roofs, and the grass was watered once a day to a water depth of $10 \mathrm{~mm}$ (test 3$)$, the heat gain reduction was substantial $\left(4.7 \mathrm{~W} / \mathrm{m}^{2}\right.$ for sand and $7.8 \mathrm{~W} / \mathrm{m}^{2}$ for silt clay). In comparison to the control roof, this results in a heat reduction of $89 \%$ for the sand green roof and $82 \%$ for the silt clay green roof. When the green roofs were watered twice a day to a water depth of $10 \mathrm{~mm}$ (test 2 ), no further improvement was achieved. The green roofs gained more heat instead of loosing $\left(8.9 \mathrm{~W} / \mathrm{m}^{2}\right.$ for sand and $13.1 \mathrm{~W} / \mathrm{m}^{2}$ for silt clay). Comparing the results of test 2 to that of test 3 , the heat gained was $89 \%$ for the sand green roof and $68 \%$ for the silt clay roof. In this case, the addition of more soil moisture does not seem to improve the heat transfer by evaporation because of the flooding that occurs. In fact, the addition of water makes the soil more thermally conductive and hastens the conductive heat transfer process. 


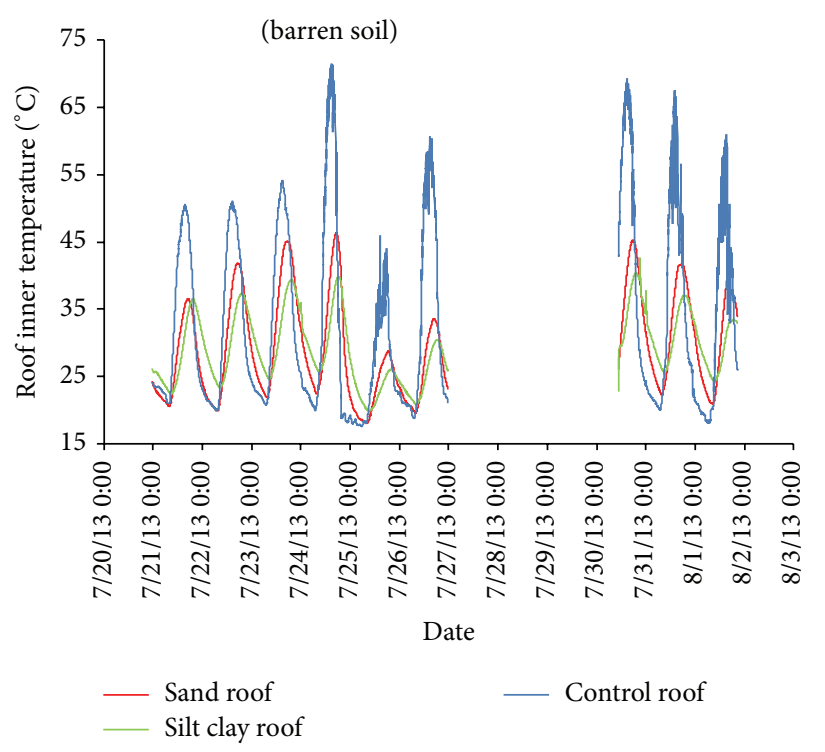

(a)

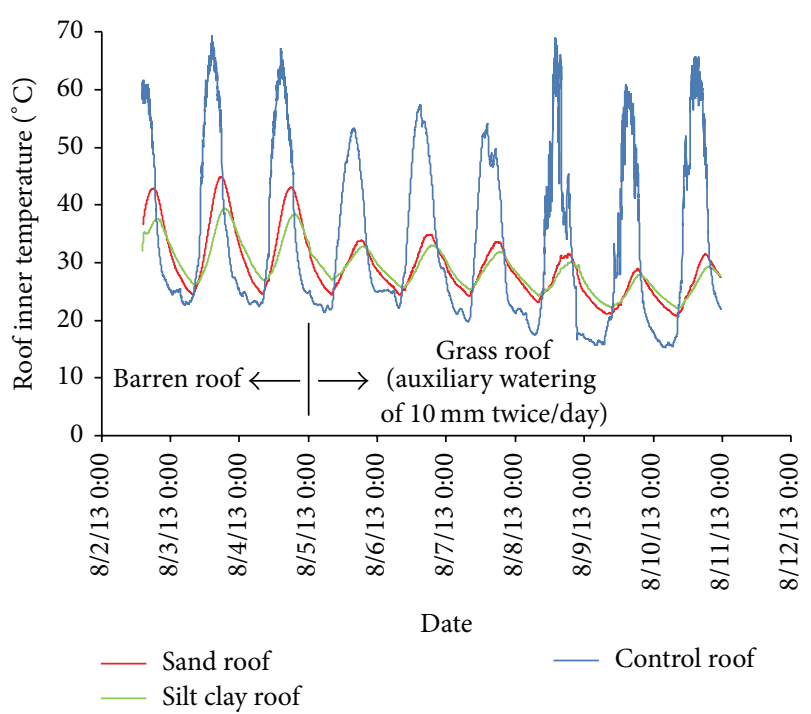

(b)

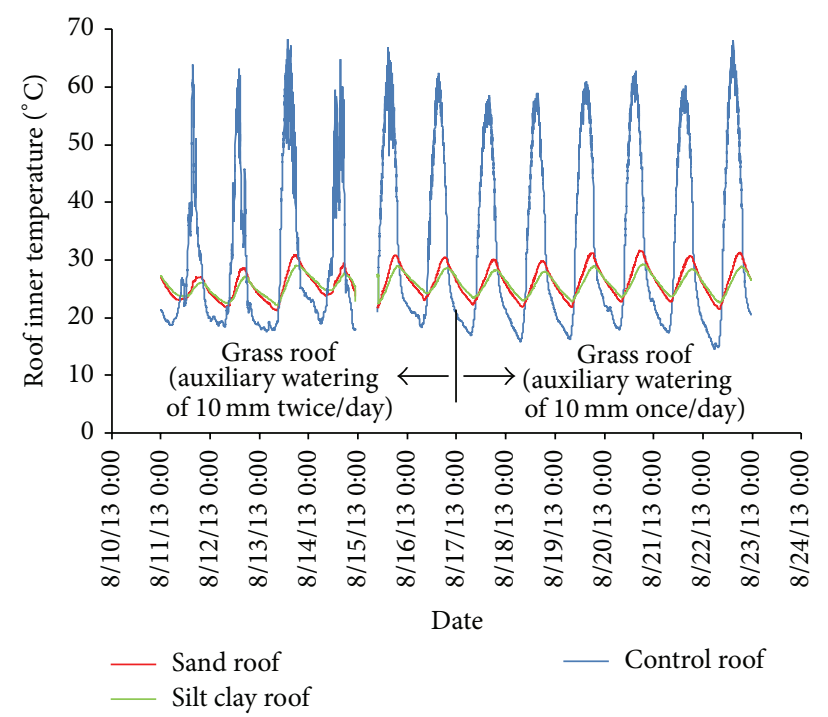

(c)

Figure 9: (a) Roof inner temperature, $T / C$ \#7 (July 21-August 1, 2013). (b) Roof inner temperature, $T / C$ \#7 (August 2-August 10, 2013). (c) Roof inner temperature, $T / C \# 7$ (August 11-August 22, 2013).

Experimental data shows the roof inner temperature of the green roof to be much lower than that of the control roof. The temperature difference between the green roof and control roof at its inner surface is plotted as function of the soil average relative moisture as shown in Figure 13. The relative moisture is calculated by dividing the actual soil moisture content by the moisture content of the soil when it is saturated. The average decrease in the roof inner temperature between the green and control roofs ranges from 4 to $7^{\circ} \mathrm{C}$, but the maximum decrease ranges from 25 to $39^{\circ} \mathrm{C}$. This is quite a substantial improvement. This difference is shown to increase with the soil moisture. However, when the soil moisture tends to its limiting value, this temperature difference starts to decline. This is due to excess free water beyond the capacity of the soil to hold it (also known as saturation, about $20 \%$ in the sand and about $45 \%$ in the clay on a gravimetric basis) that weakens soil evaporation and increases soil thermal conductivity.

The green roof net heat flux (time-averaged test data) of this study was compared with other researchers published results $[1,6,32-34]$ as shown in Figure 14. All these studies were conducted during the summer months from July to August. The results show the amount of heat that is conducted through a green roof. A wide range in the results is shown between these studies. The results of the current study $\left(14.5 \mathrm{~W} / \mathrm{m}^{2}\right)$ lie close to the mean value predicted by these researchers. The variation in the roof net heat flux is due to several factors such as: the latitude of the region where 


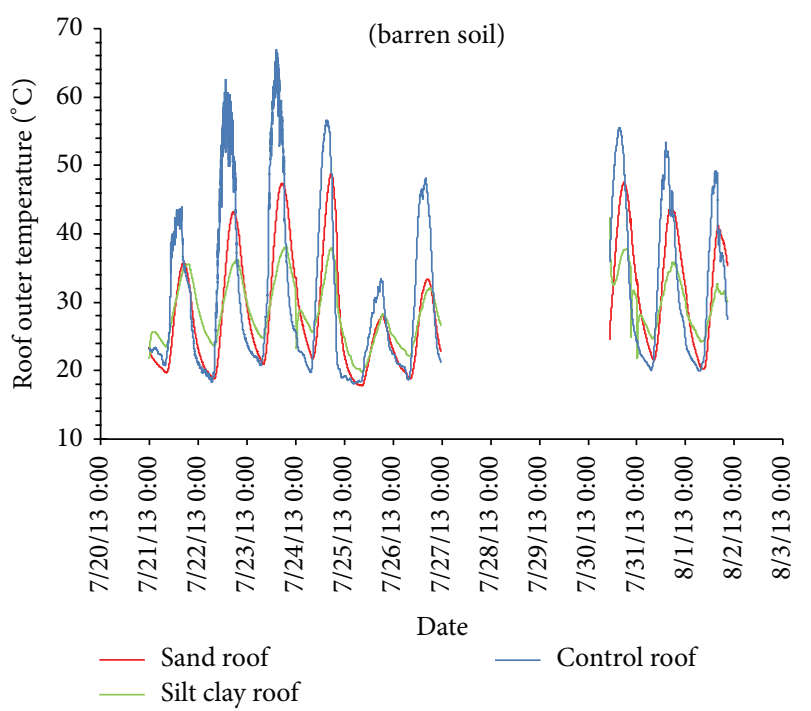

(a)

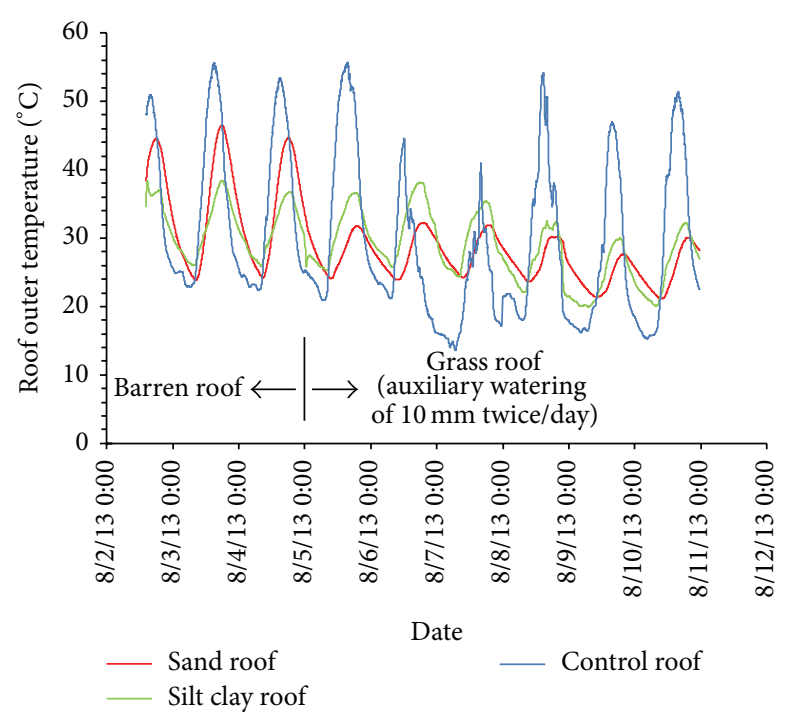

(b)

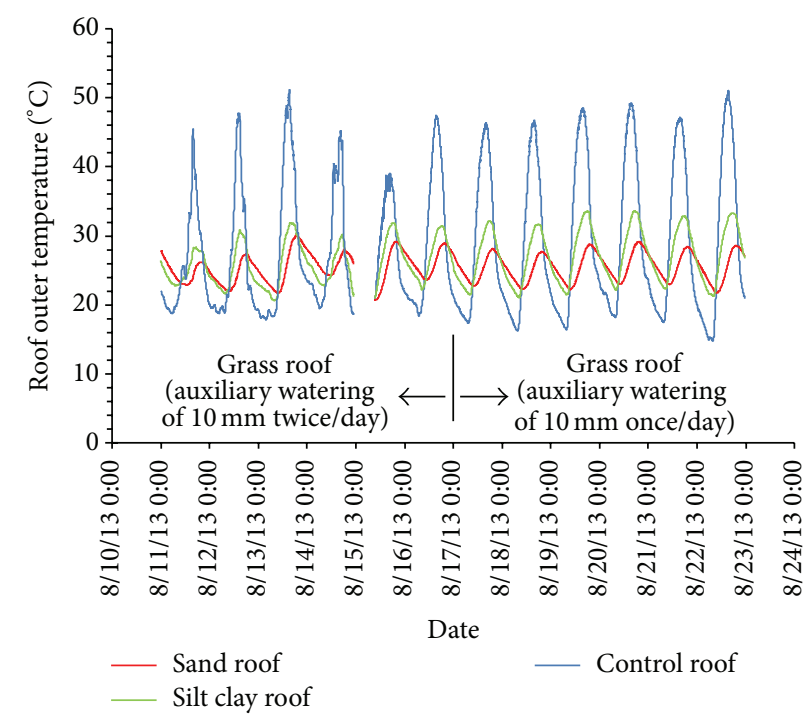

(c)

Figure 10: (a) Roof outer temperature, $T / C$ \#6 (July 21-August 1, 2013). (b) Roof outer temperature, $T / C$ \#6 (August 2-August 10, 2013). (c) Roof outer temperature, $T / C$ \#6 (August 11-August 22, 2013).

the study was performed (thus affecting the incoming solar radiation), type of soil used, relative humidity, amount of water rainfall, and the wind speed associated with the region. For example, Fioretti et al. [1] had the lowest amount of roof net heat flux $\left(6 \mathrm{~W} / \mathrm{m}^{2}\right)$ and recorded the largest amount of rain that fell during the summer months (in which, on average, it ranged between 30 to $50 \mathrm{~mm}$ of water during test days). Susorova et al. [34] had the highest amount of net heat flux $\left(29.6 \mathrm{~W} / \mathrm{m}^{2}\right)$ in the green roof tests they conducted in Phoenix, AZ. They had the highest ambient temperature among all studies, but the amount of rainwater that fell was low. In the current study, the authors recorded an amount of rainwater that was normal for west Texas region. The average wind speed associated with the current study was the highest among those researchers, while the average ambient temperature was comparable.

\section{Conclusions}

An experimental heat transfer study was conducted on a green roof built at the Alternative Energy Institute on West Texas A\&M University Campus to study the thermal performance of the roof during the summer months of West Texas. The study investigated the feasibility of using sand or local silt clay soil, and a top soil grass layer on the thermal performance of the green roof. The study also examined the effect soil moisture has on the rate of heat transfer through the roof. To perform thermal analysis on the green roof, 


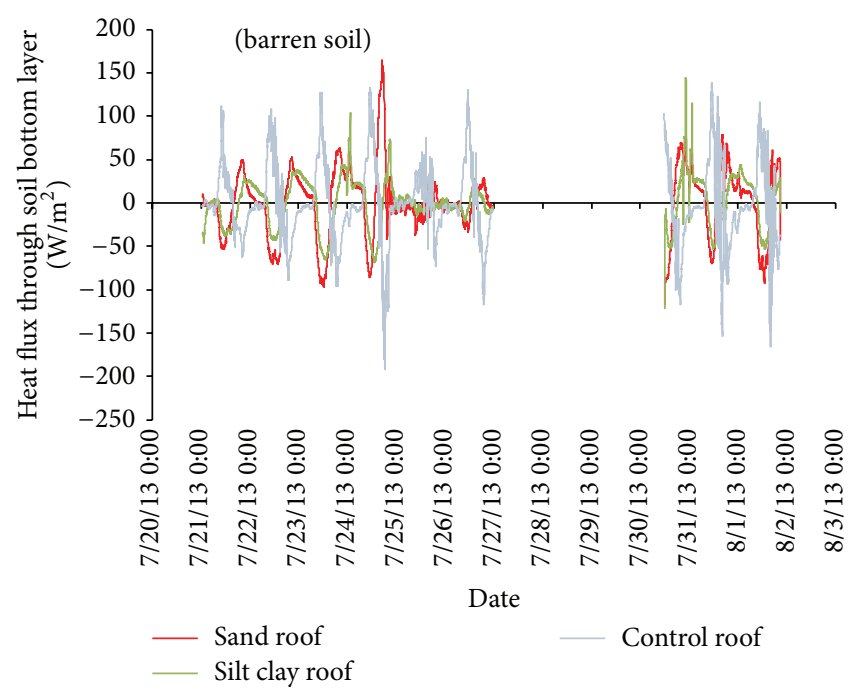

(a)

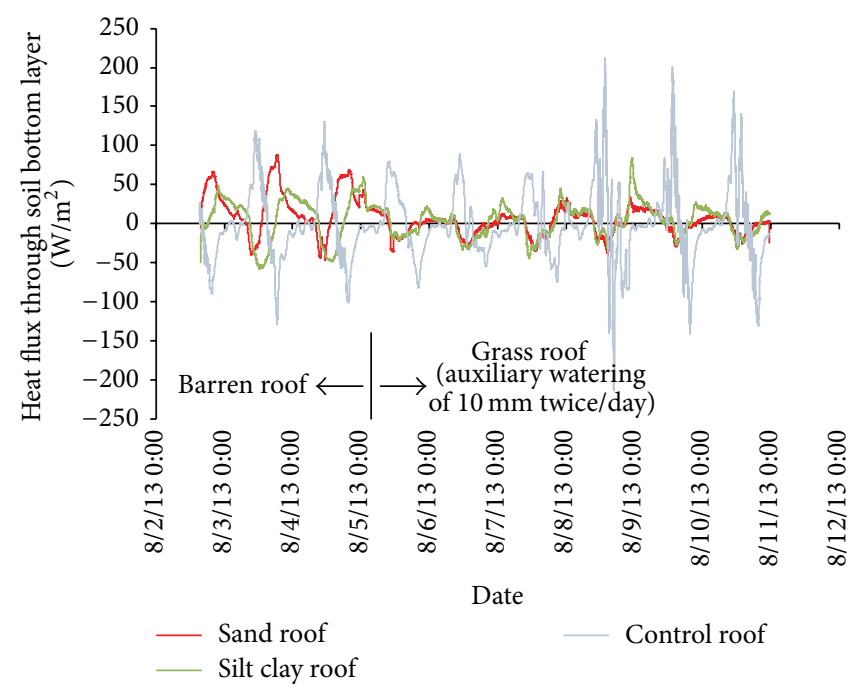

(b)

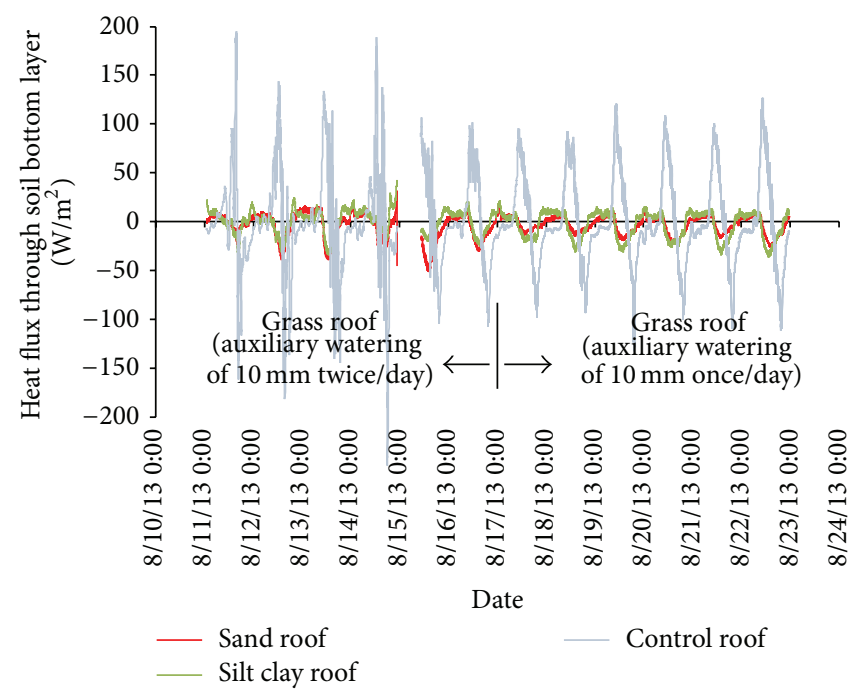

(c)

Figure 11: (a) Heat flux through soil bottom layer (July 21-August 1, 2013). (b) Heat flux through soil bottom layer (August 2-August 10, 2013). (c) Heat flux through soil bottom layer (August 11-August 22, 2013).

the thermal properties of the two soil types were experimentally determined. Based on the results of the study, the following conclusions were reached.

(i) Unlike sand, the thermal conductivity of silt clay did not increase continuously with soil moisture. The thermal conductivity of silt clay soil reached a peak at a moisture content of $25 \%$ but decreased with the addition of more water. Clay bonds tightly to water and does not let it drain easily. As a result, surface flooding occurs and the thermal conductivity of the soil/water mixture decreases as it approaches that of liquid water.

(ii) In comparison to the control roof, the sand and silt clay roof inner temperatures decreased with the increase in soil moisture content. However, as soil moisture approached saturation, the addition of more moisture to the soil became detrimental to the temperature decline.

(iii) For the sand and silt clay roofs, significant heat transfer improvement was achieved even with the absence of a top grass layer and auxiliary daily watering.

(iv) Better heat transfer conditions were achieved when the soil (sand or silt clay) was not excessively watered (10 $\mathrm{mm}$ of water/day).

(v) Green roofs with silt clay soil require more than twice the amount of soil moisture than green roofs with sand to achieve similar roof heat transfer rates.

(vi) The roof with silt clay soil had the lowest fluctuation in inner temperature between daytime and nighttime and the lowest temperature during daytime. The largest temperature fluctuation between daytime and nighttime was seen in the control roof. 


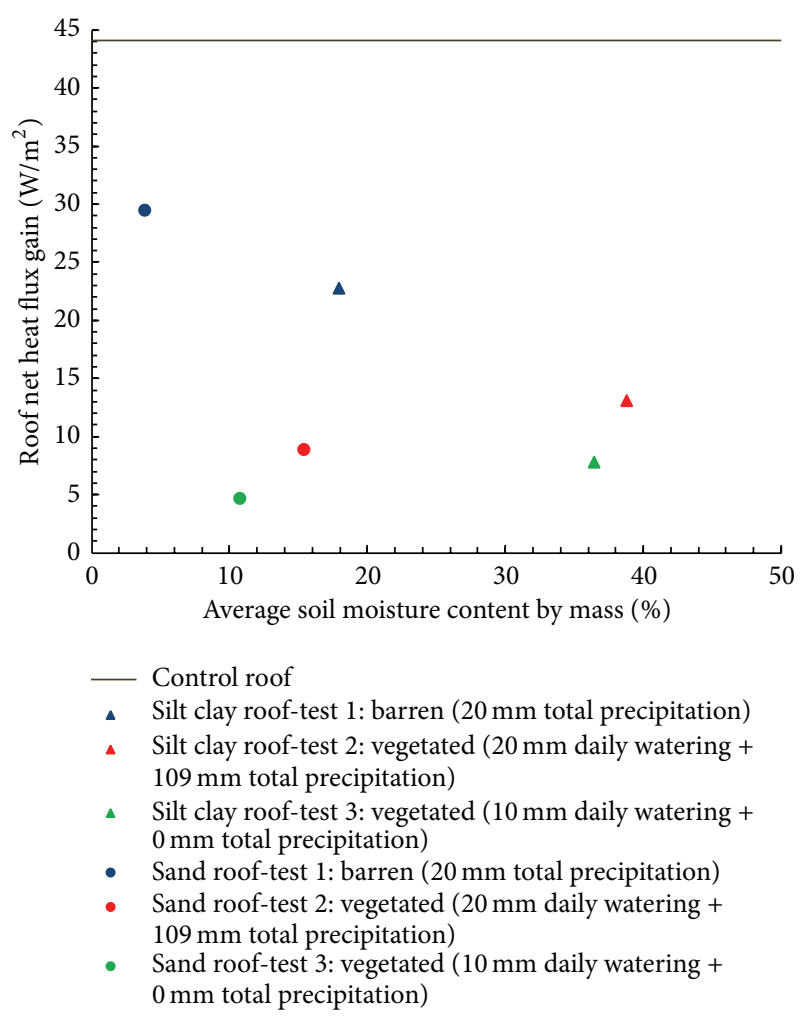

FIGURE 12: Roof net heat flux gain as function of moisture content.

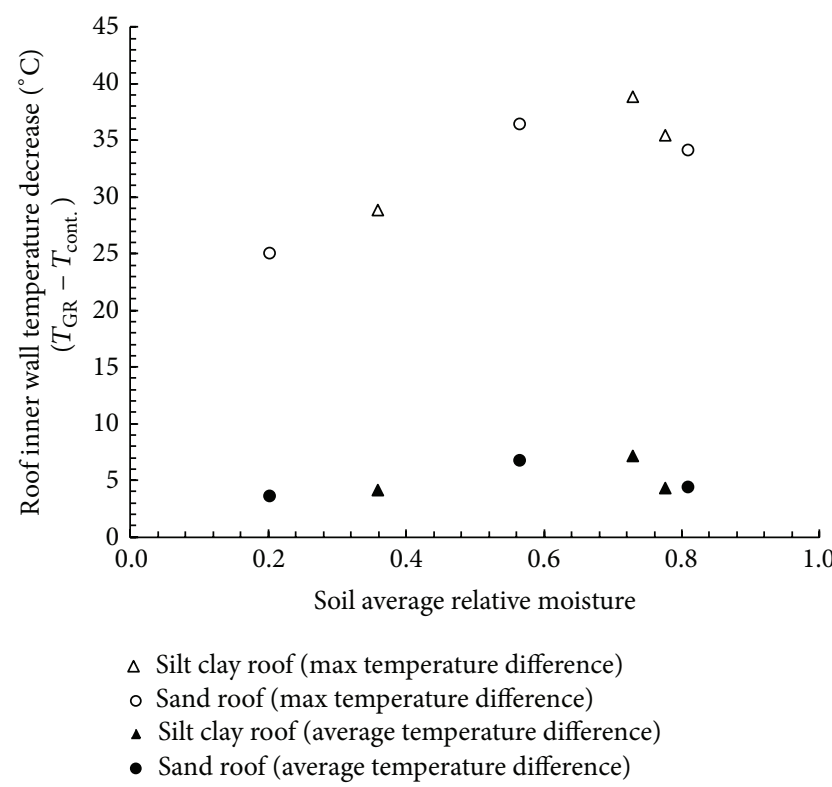

FIGURE 13: Roof inner wall temperature difference as function of soil average relative moisture.

\section{Nomenclature}
A: $\quad$ Roof surface area $\left[\mathrm{m}^{2}\right]$
$b_{o}, b_{1}, b_{2}$ : Constants for least square procedure
$c_{p}: \quad$ Specific heat $[\mathrm{J} / \mathrm{kg} \cdot \mathrm{K}]$

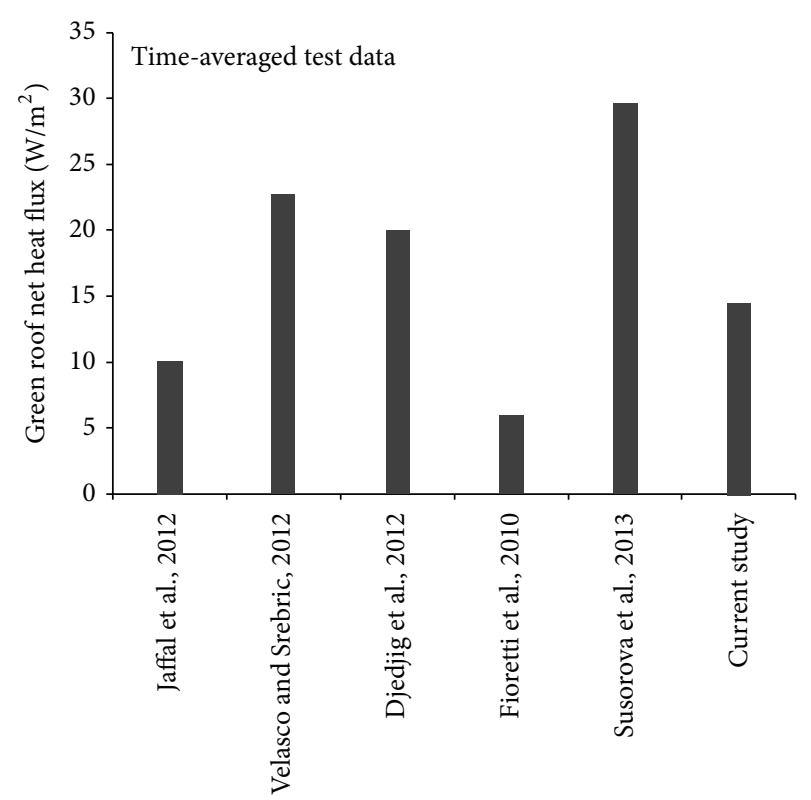

FIGURE 14: Comparison between current study roof net heat flux and other studies $[1,6,32-34]$.

$c_{v}: \quad$ Volumetric specific heat $[\mathrm{MJ} / \mathrm{m} \cdot \mathrm{K}]$

$\dot{E}_{\text {in }}: \quad$ Rate of input energy [W]

$\dot{E}_{\text {out }}: \quad$ Rate of output energy [W]

Ei: Exponential integral

Fo: $\quad$ Fourier number

$k: \quad$ Thermal conductivity $[\mathrm{W} / \mathrm{m} \cdot \mathrm{K}]$

L: $\quad$ Green roof thickness

$l: \quad$ Index

M: $\quad$ Total number of nodes

$m: \quad$ Index

$n: \quad$ Index

q: $\quad$ Heat transfer rate [W]

$q_{\mathrm{cd}, x=0}$ : Hat transfer by conduction from the green roof top surface [W]

$q_{\mathrm{cd}, x=L}$ : Hat transfer by conduction from the green roof bottom surface [W]

$q_{\mathrm{cv}}: \quad$ Heat loss by convection [W]

$q_{\mathrm{ep}}$ : Heat loss by water evaporation from the soil [W]

$q_{\mathrm{er}}: \quad$ Heat loss by emitted radiation [W]

$q_{\mathrm{lr}}: \quad$ Heat absorbed by long-wave radiation [W]

$q_{\text {net }}: \quad$ Net heat transmitted through the roof [W]

$q_{\mathrm{sr}}: \quad$ Heat absorbed by solar radiation [W]

$q_{\mathrm{tp}}: \quad$ Heat loss by transpiration [W]

$t: \quad$ Time [s]

$t_{h}: \quad$ Pulse heater duration time [s]

$t_{\text {total }}: \quad$ Total time of each test [s]

$T: \quad$ Temperature $\left[{ }^{\circ} \mathrm{C}\right]$

$T_{\text {cal }}: \quad$ Calculated temperature $\left[{ }^{\circ} \mathrm{C}\right]$

$T_{\text {exp }}$ : Experimental temperature $\left[{ }^{\circ} \mathrm{C}\right]$

$T_{i}: \quad$ Initial temperature $\left[{ }^{\circ} \mathrm{C}\right]$

$x$ : $\quad$ Distance $[\mathrm{m}]$. 


\section{Greek Symbols}

$\begin{array}{ll}\alpha: & \text { Thermal diffusivity }\left[\mathrm{m}^{2} / \mathrm{s}\right] \\ \rho: & \text { Density }\left[\mathrm{kg} / \mathrm{m}^{3}\right] \\ \zeta: & \text { Arbitrary variable } \\ \gamma: & \text { Euler-Mascheroni constant } \\ \Delta: & \text { Distance between needles for heat sensor } \\ \Delta t: & \text { Time step }[\mathrm{s}] \\ \Delta x: & \text { Grid size }[\mathrm{m}] \\ \forall: & \text { Volume }\left[\mathrm{m}^{3}\right] \\ \omega: & \text { Error. }\end{array}$

\section{Superscripts}

p: Previous time step.

\section{Conflict of Interests}

The authors declare that there is no conflict of interests regarding the publication of this paper.

\section{Acknowledgments}

The authors acknowledge West Texas A\&M University Killgore Faculty Research Program for financially supporting the project. The authors would like to thank the following undergraduate students in the Mechanical and Civil Engineering Programs for assisting in the data collection of this study: Andrew Kirschbaum, Jeremy Sprouse, Brandon Vinson, Tyler Wingo, Jeremy Neusch, Diana Ramirez, Cody Woodruff, Raymond Clonts, Marina Garcia, and Adam Hilliard.

\section{References}

[1] R. Fioretti, A. Palla, L. G. Lanza, and P. Principi, "Green roof energy and water related performance in the Mediterranean climate," Building and Environment, vol. 45, no. 8, pp. 18901904, 2010.

[2] M. Kohler, M. Schmidt, F. Grimme, M. Laar, and F. Gusmao, "Urban water retention by greened roofs in temperate and tropical climate," in Proceedings of the 38th IFLA World Congress, Singapore, 2001.

[3] J.-F. Li, O. W. H. Wai, Y. S. Li, J.-M. Zhan, Y. A. Ho, and E. Lam, "Effect of green roof on ambient $\mathrm{CO}_{2}$ concentration," Building and Environment, vol. 45, no. 12, pp. 2644-2651, 2010.

[4] J. Yang, Q. Yu, and P. Gong, "Quantifying air pollution removal by green roofs in Chicago," Atmospheric Environment, vol. 42, no. 31, pp. 7266-7273, 2008.

[5] T. van Renterghem, M. Hornikx, J. Forssen, and D. Botteldooren, "The potential of building envelope greening to achieve quietness," Building and Environment, vol. 61, pp. 34-44, 2013.

[6] I. Jaffal, S.-E. Ouldboukhitine, and R. Belarbi, "A comprehensive study of the impact of green roofs on building energy performance," Renewable Energy, vol. 43, pp. 157-164, 2012.

[7] M. Santamouris, C. Pavlou, P. Doukas et al., "Investigating and analysing the energy and environmental performance of an experimental green roof system installed in a nursery school building in Athens, Greece," Energy, vol. 32, no. 9, pp. 1781-1788, 2007.
[8] N. H. Wong, D. K. W. Cheong, H. Yan, J. Soh, C. L. Ong, and A. Sia, "The effects of rooftop garden on energy consumption of a commercial building in Singapore," Energy and Buildings, vol. 35, no. 4, pp. 353-364, 2003.

[9] D. J. Sailor, "A green roof model for building energy simulation programs," Energy and Buildings, vol. 40, no. 8, pp. 1466-1478, 2008.

[10] E. Alexandri and P. Jones, "Temperature decreases in an urban canyon due to green walls and green roofs in diverse climates," Building and Environment, vol. 43, no. 4, pp. 480-493, 2008.

[11] Y.-J. Lin and H.-T. Lin, "Thermal performance of different planting substrates and irrigation frequencies in extensive tropical rooftop greeneries," Building and Environment, vol. 46, no. 2, pp. 345-355, 2011.

[12] H. F. Castleton, V. Stovin, S. B. M. Beck, and J. B. Davison, "Green roofs; Building energy savings and the potential for retrofit," Energy and Buildings, vol. 42, no. 10, pp. 1582-1591, 2010.

[13] N. S. G. Williams, J. P. Rayner, and K. J. Raynor, "Green roofs for a wide brown land: opportunities and barriers for rooftop greening in Australia," Urban Forestry and Urban Greening, vol. 9, no. 3, pp. 245-251, 2010.

[14] K. L. Getter, D. B. Rowe, and B. M. Cregg, "Solar radiation intensity influences extensive green roof plant communities," Urban Forestry and Urban Greening, vol. 8, no. 4, pp. 269-281, 2009.

[15] T. C. Liu, G. S. Shyu, W. T. Fang, S. Y. Liu, and B. Y. Cheng, "Drought tolerance and thermal effect measurements for plants suitable for extensive green roof planting in humid subtropical climates," Energy and Buildings, vol. 47, pp. 180-188, 2012.

[16] M. Razzaghmanesh, S. Beecham, and F. Kazemi, "The growth and survival of plants in urban green roofs in a dry climate," Science of the Total Environment, vol. 476-477, pp. 288-297, 2014.

[17] B. M. Das, Principles of Geotechnical Engineering, Cengage Learning, Stamford, Conn, USA, 7th edition, 2010.

[18] G. J. Kluitenberg, K. L. Bristow, and B. S. Das, "Error analysis of heat pulse method for measuring soil heat capacity, diffusivity, and conductivity," Soil Science Society of America Journal, vol. 59, no. 3, pp. 719-726, 1995.

[19] Decagon Product Information, KD2 Pro Thermal Properties Analyzer Operator's Manual, Decagon Devices, Pullman, Wash, USA, 2010.

[20] N. H. Abu-Hamdeh, "Thermal properties of soils as affected by density and water content," Biosystems Engineering, vol. 86, no. 1, pp. 97-102, 2003.

[21] E. I. Ekwue, R. J. Stone, and D. Bhagwat, "Thermal conductivity of some compacted Trinidadian soils as affected by peat content," Biosystems Engineering, vol. 94, no. 3, pp. 461-469, 2006.

[22] D. Haynes, D. Carbee, and D. Vanpelt, "Thermal diffusivity of frozen soil," CRREL Special Report 80-38, 1980.

[23] N. H. Abu-Hamdeh, A. I. Khdair, and R. C. Reeder, "A comparison of two methods used to evaluate thermal conductivity for some soils," International Journal of Heat and Mass Transfer, vol. 44, no. 5, pp. 1073-1078, 2001.

[24] K. L. Bristow, G. J. Kluitenberg, C. J. Goding, and T. S. Fitzgerald, "A small multi-needle probe for measuring soil thermal properties, water content and electrical conductivity," Computers and Electronics in Agriculture, vol. 31, no. 3, pp. 265280, 2001.

[25] K. L. Bristow, "Measurement of thermal properties and water content of unsaturated sandy soil using dual-probe heat-pulse 
probes," Agricultural and Forest Meteorology, vol. 89, no. 2, pp. 75-84, 1998.

[26] T. Nikiforova, M. Savytskyi, K. Limam, W. Bosschaerts, and R. Belarbi, "Methods and results of experimental researches of thermal conductivity of soils," Energy Procedia, vol. 42, pp. 775783, 2013.

[27] N. H. Abu-Hamdeh, "Effect of tillage treatments on soil thermal conductivity for some Jordanian clay loam and loam soils," Soil and Tillage Research, vol. 56, no. 3-4, pp. 145-151, 2000.

[28] E. I. Ekwue, R. J. Stone, and D. Bhagwat, "Thermal conductivities of some common soils in Trinidad," The West Indian Journal of Engineering, vol. 33, pp. 4-11, 2011.

[29] G. Al Nakshabandi and H. Kohnke, "Thermal conductivity and diffusivity of soils as related to moisture tension and other physical properties," Agricultural Meteorology, vol. 2, no. 4, pp. 271-279, 1965.

[30] M. A. Oladunjoye and O. A. Sanuade, "Thermal diffusivity, thermal effusivity and specific heat of soils in Olorunsogo power plant, southwestern Nigeria," International Journal of Research and Reviews in Applied Sciences, vol. 13, no. 2, pp. 502-521, 2012.

[31] P. I. Tikhonravova, "Effect of the water content on the thermal diffusivity of clay loams with different degrees of salinization in the Transvolga region," Eurasian Soil Science, vol. 40, no. 1, pp. 47-50, 2007.

[32] P. C. T. Velasco and J. Srebric, "A heat transfer model for assessment of plant based roofing systems in summer conditions," Building and Environment, vol. 49, no. 1, pp. 310-323, 2012.

[33] R. Djedjig, S.-E. Ouldboukhitine, R. Belarbi, and E. Bozonnet, "Development and validation of a coupled heat and mass transfer model for green roofs," International Communications in Heat and Mass Transfer, vol. 39, no. 6, pp. 752-761, 2012.

[34] I. Susorova, M. Angulo, P. Bahrami, and B. Stephens, "A model of vegetated exterior facades for evaluation of wall thermal performance," Building and Environment, vol. 67, pp. 1-13, 2013. 

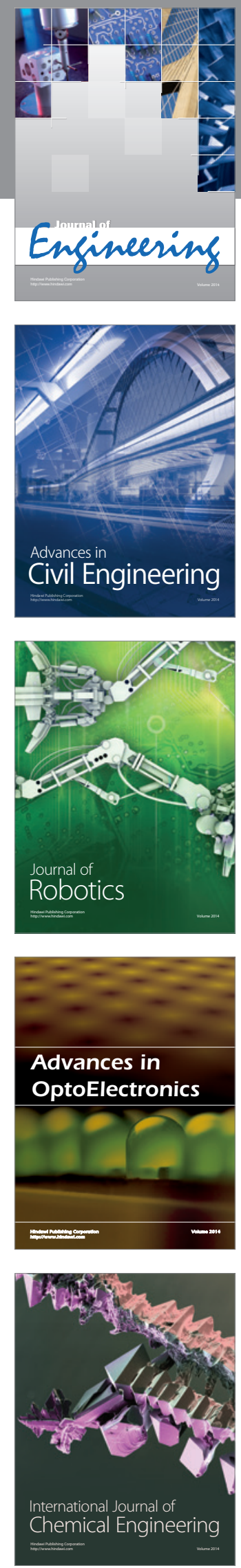

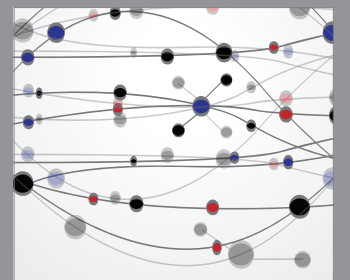

The Scientific World Journal
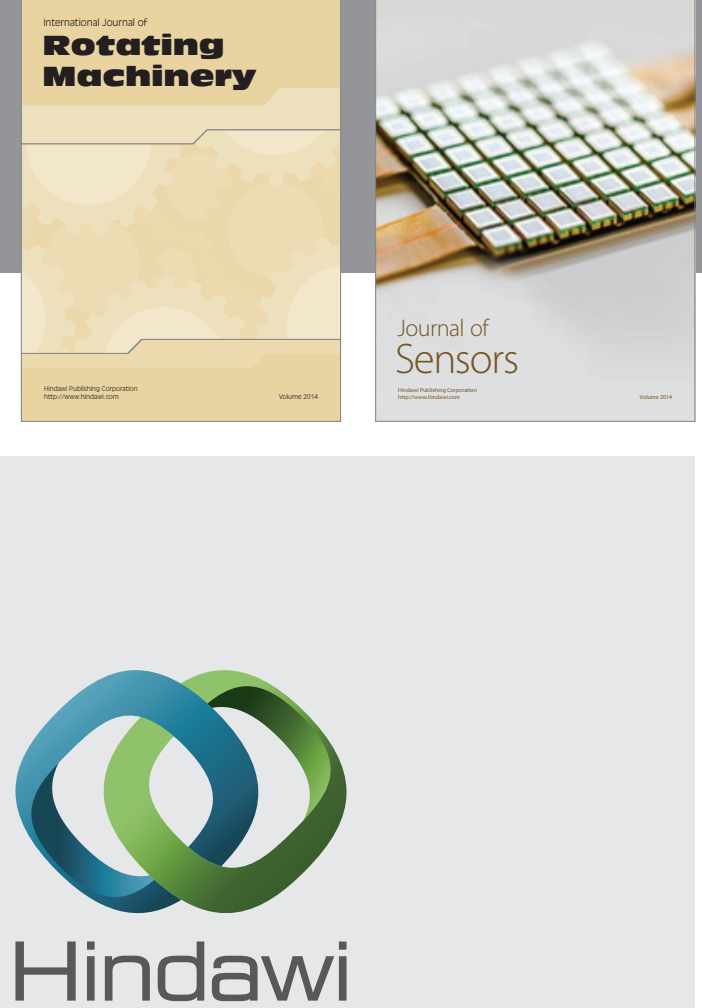

Submit your manuscripts at http://www.hindawi.com
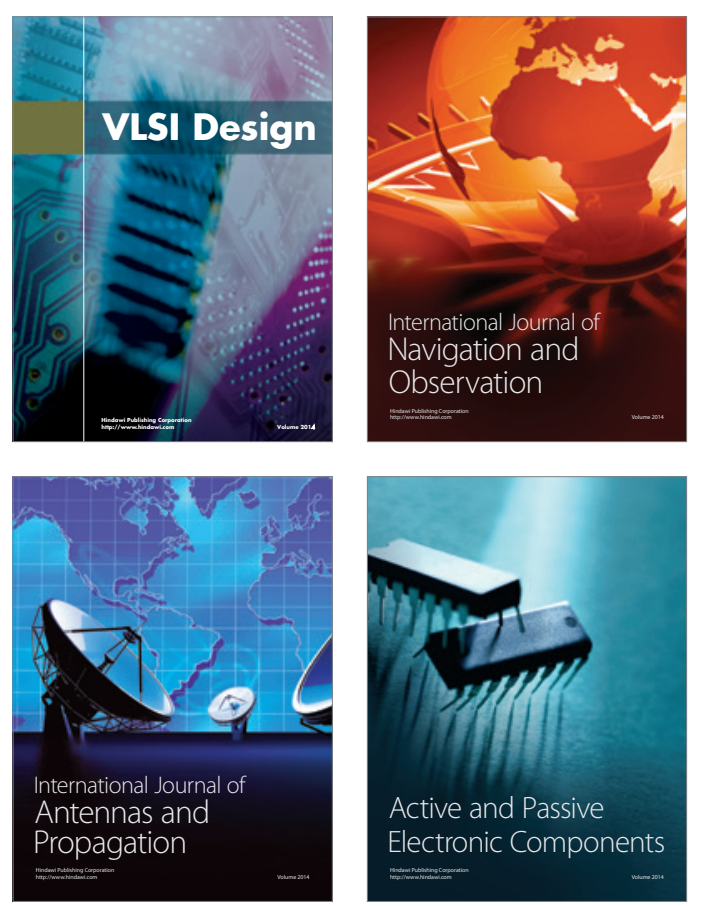
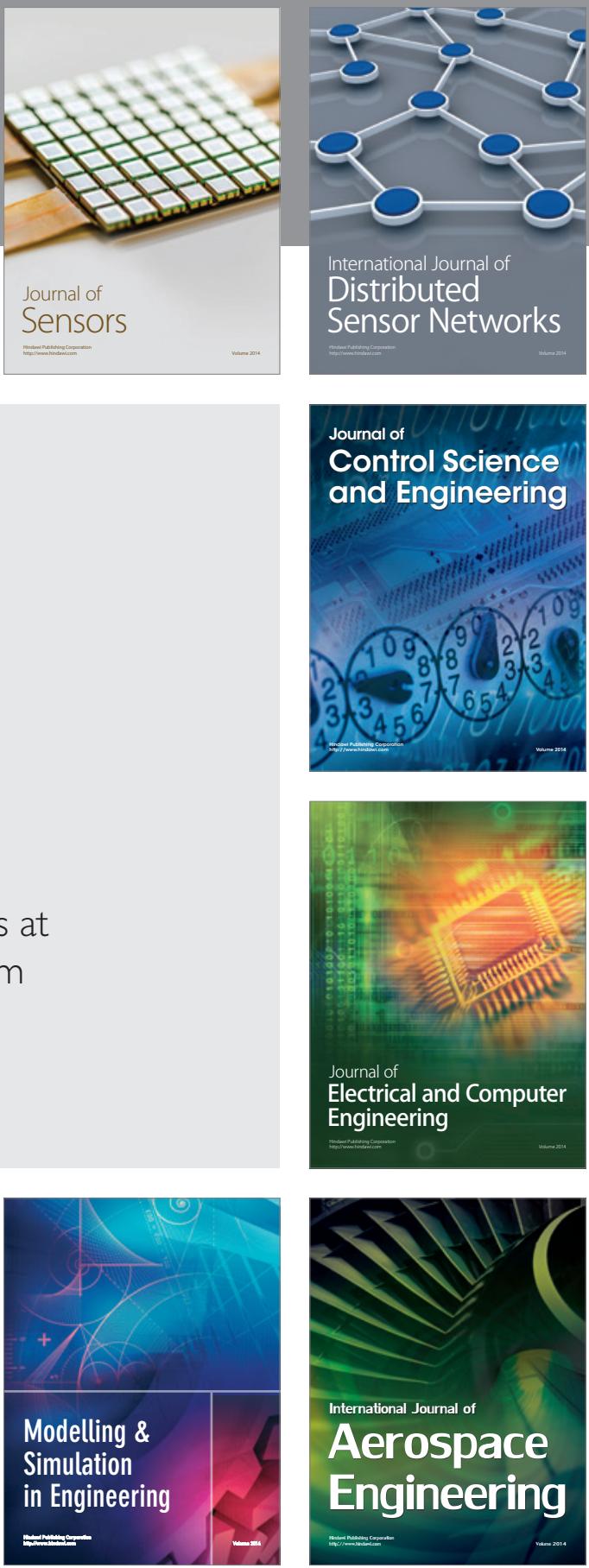

Journal of

Control Science

and Engineering
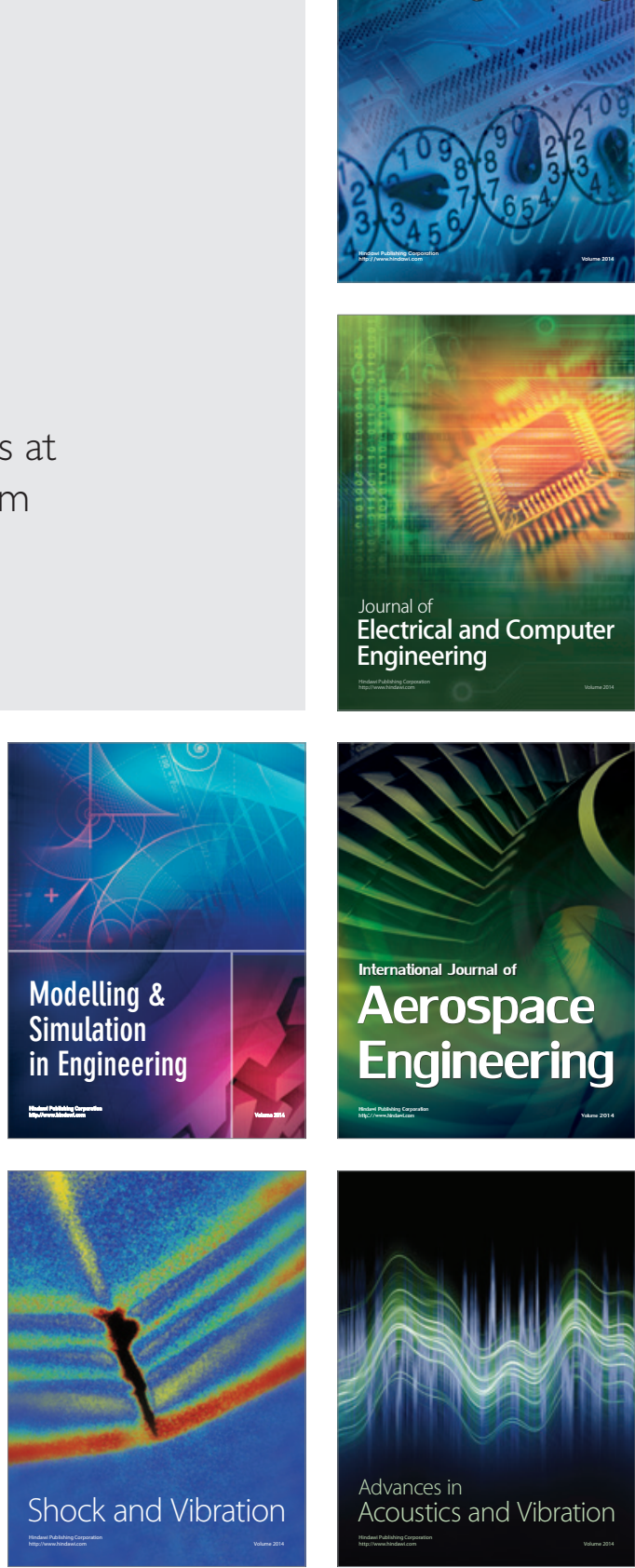